\title{
Produção e Comércio em uma Economia Agrária em Transformação: Jundiaí, 1799-1830
}

\author{
Déborah Oliveira Martins dos Reis ${ }^{1}$
}

\section{Resumo}

Através de documentação primária diversa, em especial de caráter censitário (listas nominativas de habitantes), o trabalho ocupa-se das características e mudanças da economia da localidade paulista de Jundiaí, no período 1799 a 1830. Serão enfatizadas atividades econômicas, produção e comércio levados a cabo pelos jundiaenses, assim como aspectos da escravidão e da posse de terras a eles relacionados, em um período em que a economia local passava por um processo de ampliação de sua base econômica, apresentando considerável produção para subsistência e mercado regional, assim como importante produção voltada a mercados mais distantes (identificados de um lado pela produção e circulação do milho, de outro pelo açúcar, com papel intermediário exercido pela negociação de muares).

\section{Palavras-Chave}

Produção e atividades produtivas. Comércio. Trabalho escravo. Posse de terras. Séculos XVIII e XIX. São Paulo.

\begin{abstract}
This work is based on manuscript censuses and focuses on the characteristics and changes in the economy of the São Paulo town of Jundiaí, in the period 1799 - 1830. In particular, we deal with economic elements linked to occupational structure, production and trade. Slavery and land ownership are considered. In this period, the economy was changing, with considerable production for subsistence and regional markets, as well as important production send to more distant markets (represented on one side by the production and trade of corn and on the other side by sugar, the trade of mules is observed too).
\end{abstract}

\section{Keywords}

Production and economic activities. Trade. Slavery. Land ownership. 18th and 19th centuries. São Paulo.

\section{Classificação JEL}

N36. N56. N96.

1 Professora - Universidade de Brasília (UnB) - Campus Darcy Ribeiro - Prédio da FACE - Brasília/DF Brasil - CEP: 70910-900 E-mail: deborahreis@unb.br - ORCiD: http://orcid.org/0000-0001-5840-919X. Recebido: 02/10/2017. Aceite: 06/09/2018. 


\section{Introdução}

Conhecida como "Porta do Sertão", início do caminho de muitas entradas e bandeiras - local à frente da expansão territorial colonial - Jundiaí compreendia originalmente a área que se estendia desde o Rio Grande (atualmente marco divisório entre os estados de São Paulo e Minas Gerais) até as vilas de Santana de Parnaíba e de São Paulo.

O povoamento de Jundiaí deu-se em época ignorada e de forma dispersa, mas de acordo com o Quadro do desmembramento territorial e administrativo dos municípios paulistas, por volta de 1625 é provável que já houvesse moradores na região. E somente a partir dos anos finais da década seguinte esse povoamento se intensificou, tendo a vila sido reconhecida em 1665. Dois séculos depois, em 28 de março de 1865, uma lei provincial elevou Jundiaí à categoria de cidade.

Ao final do século XVIII e primeiras décadas do século XIX, período que aqui nos interessa, faziam parte de seu território as hoje cidades de Morungaba, Itatiba, Vinhedo, Louveira, Itupeva, Várzea Paulista, Campo Limpo Paulista e Jundiaí propriamente, sendo o conjunto destas localidades o espaço jundiaense aqui analisado e cuja localização dentro do território de São Paulo pode ser visualizada no mapa abaixo (Figura 1).

Desde o início, a localidade em tela teve veio agrícola, produzindo essencialmente produtos de subsistência e abastecimento interno. Havia plantações de feijão, algodão, amendoim, milho, arroz etc. Desenvolvia-se certa criação de gado vacum e, especialmente, porcos, cujo toucinho teve alguma importância; sendo todos esses produtos eventualmente dirigidos ao comércio regional, especialmente à região das Minas Gerais e à cidade de São Paulo, com quem mantinha estreitos laços comerciais.

Além de produzir para consumo próprio e regional, em Jundiaí, encontramos lavoura de cana e ligações com a feira de animais de Sorocaba: "[...] a grande lavoura canavieira mantém a produção de açúcar $(21,91 \%$ do valor da exportação da área, um centro de reexportação do muar adquirido na feira de Sorocaba (49,00\%), e a mais importante organização do serviço de transportes da Capitania com as tropas de carga)." (Canabrava 1972, 85). 


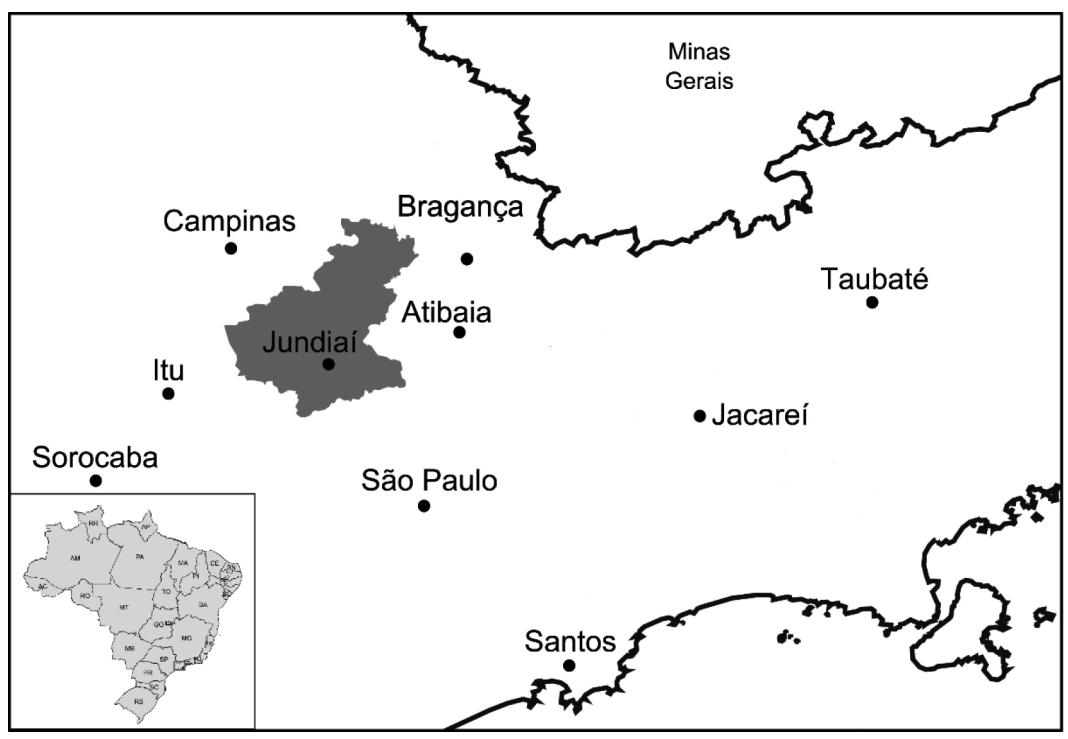

Figura 1 - Vila de Jundiaí (projeção sobre mapa atual)

Ainda que a produção de açúcar fosse relevante, não era comparável em Jundiaí às das principais localidades produtoras da região oeste (Itu, Porto Feliz, Campinas), onde se situa a própria Jundiaí:

Comparados Vale do Paraíba e Oeste Paulista, notam-se influências diferentes provocadas pelo café e pelo açúcar. Nas duas áreas manteve-se elevado o percentual de fogos com escravos que, em combinação com um alto número médio de escravos por fogo, resultou expressivo peso dos escravos no total da população, acima de 33\% nas duas regiões. Esse processo foi acompanhado por intenso crescimento no tamanho médio do plantel de escravos, particularmente no Oeste Paulista, fruto da atividade açucareira, com nivel de concentração maior nessa atividade do que na cafeeira. Isso explica a elevada média de escravos por fogo, de 2,9, nessa região. (Luna 2009b, 342-343). 
Sempre pautada no trabalho cativo, de localidade com produção agrícola de subsistência e excedentes enviados a mercados regionais, Jundiaí passou a localidade agrícola de subsistência dependente de novo e importante veio exportador, surgido com impulsos tomados na segunda metade do Setecentos por São Paulo com Morgado de Mateus, estimulando a lavoura canavieira, quando as minas das Gerais já se esgotavam e paulistas e mineiros buscavam alternativas ocupando o interior paulista, "[...] as terras não são tão favoráveis à cana quanto as de Campinas: no entanto, ela é cultivada com bons resultados no sopé da Serra do Japi, cadeia de montanhas que se estende ao sul da cidade." (Saint-Hilaire 1976, 114).

Ou seja, situada que está em área limítrofe à região da capital e o oeste paulista, apresenta características de ambas as regiões, ${ }^{1}$ quais sejam, considerável produção para subsistência e mercado regional, assim como importante produção para exportação internacional (extremos apresentados ao longo deste trabalho, em especial, pela produção e circulação do milho e do açúcar, com papel intermediário exercido pela negociação de muares).

Nesse horizonte, Jundiaí apresenta-se como lócus privilegiado para estudo. Tentamos, pois, compreender as características da sua base produtiva/mercantil, explorando atividades econômicas, produção e comércio levados a cabo pelos jundiaenses, assim como aspectos populacionais da escravidão e da posse de terras condicionados e condicionadores dessa dinâmica ao final do Setecentos e nas primeiras décadas do século XIX.

Para tal, apoiamo-nos em uma gama de fontes documentais manuscritas relativas a Jundiaí de 1799 a 1830 . O principal e maior corpus documental consultado é constituído pelas listas nominativas de habitantes, arquivadas sob a rubrica maços de população no AESP (Arquivo Público do Estado de São Paulo). Acrescem a elas mapas comparativos de produção e comércio e de maneira mais pontual o inventário de bens rústicos. ${ }^{2}$

1 Alguns autores a estudam vinculada à região da capital, a exemplo Canabrava (1972), Marcílio (2000) e Nozoe (2008); outros entendem como pertencentes à região açucareira do Oeste Paulista, como Bacellar (1997) e Luna (2009)

2 Os mapas populacionais são documentos manuscritos, em tese anuais, que contêm a relação nominal dos habitantes de diversos municípios da capitania/província de São Paulo. Dentro do período considerado em nossa análise, selecionamos para Jundiaí documentos realizados entre intervalos aproximados de 5 anos iniciando-se em 1799, a saber: 1799, 1803, 1808, 1812, 1816, 1822, 1825 e 1830 (para alguns dos anos excluídos da análise a lista inexiste ou encontra-se consideravelmente incompleta ou deteriorada). Os moradores de cada domicílio eram descritos de acordo com sua relação com o "chefe de fogo" (cônjuge, filhos, agregados, escravos), que encabeçava a lista e para quem, via de regra, apareciam as informações mais completas. Em regra, as atividades econômicas/produtivas foram apresentadas de forma bastante genérica, fornecendo indícios mais dos setores em que a pes- 
O trabalho está estruturado em cinco seções, incluindo esta breve introdução e as considerações finais. A próxima dedica-se à produção e ao comércio, em que são apresentados os principais produtos encontrados nos domicílios jundiaenses e características atinentes à forma que assume a produção e circulação na localidade, com destaque para o açúcar e o milho, dois de seus principais produtos. Em seguida, esboça-se um panorama sobre as atividades produtivas levadas a cabo em Jundiaí. A seguir, acompanha-se o evolver populacional em seu conjunto, a estrutura fundiária (concentração e utilização das terras), assim como a presença do trabalho de escravos.

\section{Produção e Comércio}

Inicialmente, observamos os diversos produtos cultivados, cuja produção foi mencionada nas várias listas nominativas de Jundiaí consultadas e que estão apresentados na Tabela 1 e no Gráfico 1 abaixo. ${ }^{3}$ Vale notar que a

soa estava envolvida do que das suas condições e sua função exata, como no caso dos lavradores, por exemplo. "Como definir as diferenças ou similaridades entre lavradores, agricultores, roceiros, planta para o gasto, planta para viver?" (Bacellar 2008, 121). Para os chefes de domicílio eram apontadas as ocupações econômicas realizadas (atividade principal do fogo) incluindo, em certos anos, dados sobre a produção levada a cabo, sendo mencionados tipo de produto, quantidade e destino dado à produção (consumo próprio ou mercado). Não era informada a área cultivada. Para contextualização das condições de sua produção e para análise crítica dos mapas populacionais ver, por exemplo, Fernandez (1989), Nozoe e Costa (1991), Bacellar (2008).

Informações econômicas que abrangem produção e comércio (compra e venda de distintos produtos), as quantidades produzidas e negociadas, seus destinos/origens, assim como os preços levados a cabo em diferentes mercados são observados nos quadros-resumo denominados Mapas de comércio, encontrados junto aos maços de população no AESP. Com o intuito de montarmos séries de dados completas o mais possível e de alguma forma consistentes foram utilizados todos os quadros localizados para o período 1799 - 1830 .

Por fim, no período que consideramos, o único documento a arrolar as propriedades e os proprietários de terra foi o Cadastramento de terras - ou Inventário de bens rústicos, como é conhecido -, com a "relação dos sítios e terras" para o ano de 1818. Encontramos descritos neste "tombamento" a relação das propriedades existentes nas localidades, seus proprietários e medidas. Em boa monta aparecia também a forma de aquisição do quinhão declarado, assim como, em alguns casos, a utilização de terras e divisas. São mencionadas também se os proprietários ali residem ou, eventualmente, as outras pessoas que vivem e/ou trabalham nas terras descritas, ademais era mencionada a quantidade, sem qualquer menção a idade ou sexo, o número de escravos possuídos, empregados ou não na produção realizada na propriedade.

3 O cultivo da cana foi auferido a partir da presença do açúcar e/ou da aguardente. O ano de 1812 foi excluído dos números apresentados, pois apresentou apenas 21 domicílios com algum tipo de menção ao cultivo levado a cabo, sendo que em 17 deles encontramos produto da atividade de engenhos, o que certamente não é representativo da realidade produtiva da vila naquele momento. Ainda que a presença do feijão seja bastante elevada nos fogos, assim como do arroz e do algodão em momentos 
elaboração da Tabela e do Gráfico foi baseada no número de fogos com algum tipo de produção declarada e que corresponde aos seguintes números absolutos: 339 em 1779, 429 em 1803, 233 (em 1808), 499 (1816), 428 (1822), 535 (1825) e 397(1830). Esses números representam um mínimo de 31,9\% (1808) de todos os fogos da localidade e o máximo de 61,1\% (1825), sendo o total de fogos arrolados: 735 em 1779, 743 (1803), 731 (1808), 863 (1816), 765 (1822), 875 (1825) e 910 (1830).

Tabela 1 - Gêneros plantados e presença concomitante dos diferentes gêneros nos fogos (1799 a 1830)

\begin{tabular}{lccccccc}
\hline \hline \multicolumn{1}{c}{ CULTURAS } & $\mathbf{1 7 9 9}$ & $\mathbf{1 8 0 3}$ & $\mathbf{1 8 0 8}$ & $\mathbf{1 8 1 6}$ & $\mathbf{1 8 2 2}$ & $\mathbf{1 8 2 5}$ & $\mathbf{1 8 3 0}$ \\
\hline MILHO & $90,0 \%$ & $99,8 \%$ & $94,4 \%$ & $99,0 \%$ & $99,8 \%$ & $99,6 \%$ & $99,5 \%$ \\
FEIJÃO & $54,9 \%$ & $70,2 \%$ & $81,1 \%$ & $66,7 \%$ & $62,4 \%$ & $77,9 \%$ & $66,5 \%$ \\
ALGODÃO & $15,6 \%$ & $14,7 \%$ & $24,0 \%$ & $13,6 \%$ & $7,9 \%$ & $2,8 \%$ & $3,3 \%$ \\
ARROZ & $4,7 \%$ & $22,1 \%$ & $14,2 \%$ & $12,6 \%$ & $12,9 \%$ & $11,8 \%$ & $15,9 \%$ \\
AMENDOIM & - & $2,6 \%$ & $0,4 \%$ & $5,2 \%$ & $0,5 \%$ & $0,2 \%$ & - \\
TRIGO & - & - & - & $0,6 \%$ & - & - & - \\
CANA & $6,2 \%$ & $4,2 \%$ & $9,0 \%$ & $3,8 \%$ & $7,2 \%$ & $6,0 \%$ & $4,1 \%$ \\
MANDIOCA & - & - & $0,4 \%$ & $0,2 \%$ & - & - & - \\
CAFÉ & - & - & - & - & - & - & $0,3 \%$ \\
MAMONA & - & - & - & $0,2 \%$ & - & - & - \\
FUMO & $0,3 \%$ & - & - & $0,4 \%$ & - & $0,2 \%$ & - \\
\hline \hline
\end{tabular}

Fonte: AESP, Maços de População, Jundiaí: anos selecionados, exclusive 1812

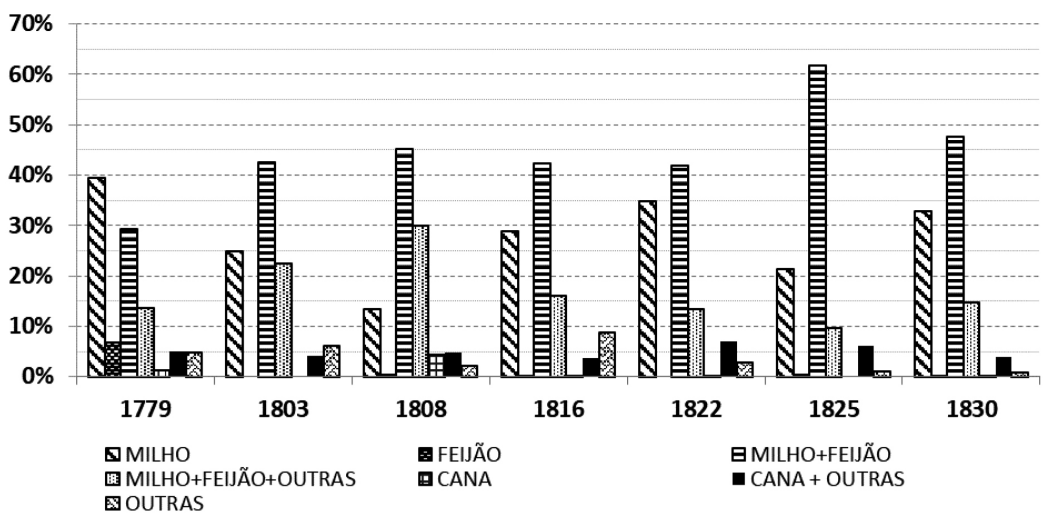

Gráfico 1 - Percentual de fogos com presença dos diversos gêneros cultivados (1799 a 1830) componentes do comércio local, em volume e em composição de valores 
De maneira clara, em termos de abrangência e presença nos domicílios, encontramos total supremacia do milho, espraiado por $90 \%$ das declarações em 1799, 94,4\% em 1808 e estando praticamente na totalidade dos fogos com algum tipo de produção mencionada em $1830 .{ }^{4}$ Todavia, o cereal apareceu como cultura exclusiva em comparativamente pequena fatia dos fogos: máximo de 35,3\% em 1799, o que correspondia a 134 domicílios, e o mínimo de $13,3 \%$ no ano de 1808, quando 31 chefes arrolaram apenas o milho em suas declarações. Ou seja, ao menos 56,1\% dos plantadores de milho (1799) mantiveram, concomitantemente ao longo dos anos, outro tipo de cultivo que merecesse algum destaque a ponto de ser referido, percentual este que foi máximo em 1808, 85,9\%.

À exceção da cana, que para além dos derivados mais grosseiros e baratos (rapadura e aguardente), sabidamente participava do comércio intrarregional e para além-mar, todos os demais produtos estavam entre aqueles que designamos como de subsistência, ainda que não necessariamente autossubsistência. Um maior número de plantações torna, para aqueles que as praticam, a especialização mais difícil, o que indica, possivelmente, maior autoconsumo, ou seja, produção em quantidades limitadas que atendessem às necessidades das próprias unidades produtivas. Esse foi certamente $o$ caso daqueles que mencionaram grande número de gêneros.

Importante notar que mesmo naquelas unidades ligadas ao cultivo da cana para beneficiamento, ou seja, nas propriedades em que existiam engenhos, o cultivo dos demais gêneros esteve presente: $81 \%$ dos senhores de engenho declararam também outros produtos em 1799, 50\% em 1808, e ao menos $95 \%$ nos demais anos, chegando à totalidade em 1803 e 1825. Facilmente compreensível, posto ser a atividade açucareira bastante intensiva em mão de obra, ou seja, em trabalho de cativos - aí estava empregada parcela elevada dos escravos da vila de Jundiaí entre 1799 e 1830, como se verá - que precisavam se alimentar.

4 Econtramos nos documentos de Jundiaí o seguinte número total de $\mathrm{f}$. 
Consideradas as diferentes medidas (volume, peso ou unidades) para os distintos bens, utilizamos a moeda como unidade de mensuração. Os resultados do processo produtivo da vila e seu termo, tomando-se os "bens finais" produzidos, observados através do valor total do produto ao longo do tempo, ${ }^{5}$ mostrado na Tabela 2 , levam a interessantes considerações.

Sendo amplamente disseminado, o milho apresenta participação incontestável ao se precificar os bens. Ao lado do açúcar, manufaturado que tem, via de regra, elevados preços no mercado, como se verá, o cereal em tela foi um dos principais representantes da composição do produto jundiaense durante as mais de três décadas consideradas. Milho e açúcar (principalmente o açúcar fino ou branco) foram os dois principais produtos locais em valor e oscilaram ao longo do tempo no primeiro e segundo postos. Assim, não houve uma tendência clara de variação ao longo do tempo ou algum patamar padrão de valor em que houvesse se estabelecido cada um dos bens.

Tabela 2 - Participação percentual dos diversos gêneros no valor do produto (1798 a 1830)

\begin{tabular}{|c|c|c|c|c|c|c|c|c|c|}
\hline Anos & $\begin{array}{c}\text { Milho } \\
\%\end{array}$ & $\begin{array}{c}\text { Açúcar } \\
\%\end{array}$ & $\begin{array}{c}\text { Outros } \\
\%\end{array}$ & $\begin{array}{c}\text { Total } \\
\%\end{array}$ & Anos & $\begin{array}{c}\text { Milho } \\
\%\end{array}$ & $\begin{array}{c}\text { Açúcar } \\
\%\end{array}$ & $\begin{array}{c}\text { Outros } \\
\%\end{array}$ & $\begin{array}{c}\text { Total } \\
\%\end{array}$ \\
\hline $1798^{*}$ & 36,9 & 53,6 & 9,5 & 100,0 & $1818^{*}$ & 17,2 & 55,4 & 27,4 & 100,0 \\
\hline 1799* & 35,0 & 26,9 & 38,1 & 100,0 & $1822^{*}$ & 45,6 & 28,8 & 25,6 & 100,0 \\
\hline $1799 * *$ & 29,4 & 37,0 & 33,6 & 100,0 & $1822 * *$ & 36,9 & 34,7 & 28,4 & 100,0 \\
\hline $1803^{* *}$ & 55,5 & 17,9 & 26,6 & 100,0 & $1825^{*}$ & 38,5 & 31,6 & 29,9 & 100,0 \\
\hline $1808^{* *}$ & 55,5 & 20,1 & 24,4 & 100,0 & $1825^{* *}$ & 41,4 & 40,9 & 17,7 & 100,0 \\
\hline $1814^{*}$ & 33,4 & 37,3 & 29,3 & 100,0 & $1827^{*}$ & 40,5 & 41,0 & 18,5 & 100,0 \\
\hline $1815^{*}$ & 32,3 & 41,5 & 26,2 & 100,0 & $1828^{*}$ & 39,6 & 38,6 & 21,8 & 100,0 \\
\hline $1816^{*}$ & 29,0 & 44,2 & 26,8 & 100,0 & $1829 *$ & 40,0 & 26,2 & 33,8 & 100,0 \\
\hline $1816^{* *}$ & 29,6 & 43,3 & 27,1 & 100,0 & $1830 *$ & 34,0 & 43,3 & 22,7 & 100,0 \\
\hline $1817^{*}$ & 22,0 & 35,8 & 42,2 & 100,0 & $1830 * *$ & 45,2 & 22,5 & 32,3 & 100,0 \\
\hline
\end{tabular}

Em que pesem as diferenças encontradas entre os dados obtidos através das observações atinentes ao diferentes fogos no arrolamento populacional dos anos por nós considerados, ${ }^{6}$ e os montantes retirados dos mapas de

5 Devido às características dos Mapas de produção, comércio e preços consultados e os próprios arrolamentos populacionais, o valor de cada bem foi calculado multiplicando-se a quantidade pelo preço médio para consumo na vila, sendo o preço médio considerado como $P M e=\frac{(\text { preçomínimo }+ \text { preçomáximo })}{2}$.

6 Por seu caráter de censo populacional, em regra, as atividades econômicas/produtivas foram apresentadas de forma bastante genérica nas listas nominativas, fornecendo indícios mais dos setores 
produção, chama atenção os anos 1803-1808, em que o percentual devido ao milho atingiu cerca de $55 \%$, seu mais alto valor, enquanto o açúcar, nestes mesmos anos, esteve ao redor de 18 a 20\% - todavia, há que mencionar que em 1808 o preço do milho atingiu seu maiores valores, como exposto mais adiante. Por outro lado, a partir de 1814 a participação do açúcar cresceu consideravelmente atingindo seu máximo em 1818, com $55,4 \%$ do produto daquele ano. A sua vez, a participação do milho viu-se gradativamente reduzida, de $33,4 \%$ em 1814 a $17,2 \%$ naquele mesmo ano de 1818 , em que se verificou sua menor participação considerado todo o período de 1798 a $1830 .^{7}$

O milho e o açúcar eram utilizados para consumo na própria vila e seu termo e faziam parte da pauta de exportações jundiaenses (que compunham em diferentes proporções e com vistas a diferentes destinos), assim como distintos eram os aspectos diversos de seu cultivo.

A produção de milho, a mais espraiada delas, era levada a cabo em propriedades que mencionaram ao menos um alqueire do cereal e que respondiam por não mais de $2,2 \%$ do valor total exportado ao longo dos anos que seguiram 1798 até 1825 , chegando a 3,5\% em 1827, 4,5\% no ano seguinte e seu máximo, $6,7 \%$ em 1829, reflexo da pequena parcela da produção que participava do mercado para além das fronteiras do município, especial-

em que a pessoa estava envolvida do que das suas condições e sua função exata ou mesmo produção ou capacidade produtiva. A sua vez, os mapas de população foram constituídos com o objetivo de apresentar estatísticas marcadamente econômicas. Assim sendo, a comparação dos totais apresentados nos diferentes mapas com os totais das respectivas listas nominativas apontam para montantes bastante divergentes. Em regra, com informações de menor monta encontradas na listagem por fogos. Ademais, existem informações nos mapas que não constam dos recenseamentos, mormente naqueles mapas relativos à importação e exportação. Isto implica a existência de fontes de informações que vão além das próprias listas nominativas a que os mapas estavam vinculados e do nosso conhecimento. Vale lembrar que se trata de fonte primária manuscrita, em que as diferenças podem decorrer da ausência de dados devida a diferentes motivos como: dificuldades, empenho, preocupação, paciência, vontade daqueles responsáveis pela feitura de tal documento ou até mesmo a não sobrevivência de parte desses documentos. Por esse motivo trabalhamos com as duas documentações de forma paralela e complementar e também com valores percentuais (ou seja, com a participação relativa dos valores anotados nos documentos).

7 Os demais gêneros produzidos localmente também não tiveram tendência identificável no longo prazo, mas aguardente, feijão e capados merecem ser citados. A aguardente teve uma participação média ao redor de 3\%, sendo seu máximo identificado na lista nominativa de 1803: 6,7\%. O feijão, apesar de sua participação insignificante nos mapas de $1815(0,4 \%)$, no ano anterior havia respondido por $16,2 \%$ e no ano seguinte por $7-8 \%$, percentual que se repetiu em meados da década de 1820 , e que foi seguido por consideráveis $22 \%$ em 1817. Os capados apareceram na documentação desde 1799 , certamente em detrimento ao toucinho que, terceiro principal responsável pelo valor do produto jundiaense em 1799, 21,8\% de acordo com o mapa de comércio, desapareceu definitivamente da relação de bens produzidos já no arrolamento populacional do mesmo 1799. Os capados atingiram seu pico em 1815 , com $19,3 \%$, e 1829 , com $19,9 \%$, percentual pouco alterado no ano seguinte: $18 \%$. 
mente para um produto que se manteve como importante em valor, assim como em volume, ao longo de todo o período em tela, tendo sua produção chegado a superar os 60 mil alqueires nos anos finais estudados, que correspondem ao período com maior percentual de sua produção levada a outros mercados: 4,1\% (1827), 4,7\% (1828) e 5,5\% (1829).

Conforme exposto na Tabela 3 (ainda que o significado efetivo das produções nas listas nominativas seja de difícil compreensão, havendo declarações apenas do montante vendido, outras com menção ao montante produzido e à parte dele levado ao comércio e ainda declarações nas quais foi apenas dito "colheu") fato é que para atingir esse montante produzido e vendido o grupo dos produtores de milho teve sua "colheita" média aumentada de 59,3 alqueires por unidade produtiva em 1799 , para 109,8 em 1816, e de 88,2 alqueires em 1822 para 144,2 alqueires em 1830, com destaque para os produtores de 100,1 a 300 alqueires, pois foram de $6 \%$ dos cultivadores em 1799 para 17,2\%, pouco mais de 25 anos depois, e para $19,5 \%$ após cinco anos, quando se destacam também os maiores produtores locais do grão (com mais de 500 alqueires arrolados), contados em número de 16 em 1825 e 12 em 1830, quando em 1799 eram apenas três. Todavia, independente do momento, as produções mais representativas da realidade produtiva na vila eram aquelas produzindo entre 10,1 e 50 alqueires de milho - que responderam por não menos de $46,5 \%$ dos domicílios (1830).

Apesar da presença de produtores responsáveis pela colheita de consideráveis volumes de milho, estes não eram necessariamente aqueles responsáveis pela comercialização do cereal. Entre os poucos fogos explicitamente vendedores de milho encontramos, ao longo do tempo, aqueles enquadrados em todas as faixas produtivas.

Em 1799, os menores plantadores venderam 13,3\% da sua produção e deixaram de registrar tal destino para ela a partir de então, quando recorrentemente a faixa dos 100,1 aos 300 alqueires respondeu pelos maiores percentuais vendidos, sendo superada em 1830 pela faixa seguinte, o que afirmamos com certa reticência devido ao pequeno número de observações para análises estatísticas mais apuradas. Observada a participação de cada faixa de produção no volume total vendido verificamos, em regra, serem os principais vendedores os que produziam/colhiam entre 10 e 300 alqueires; apenas em 1822, ano para o qual temos somente cinco observações de venda, estas concentraram-se nos domicílios com mais de 100 alqueires do cereal declarados. 
Em 1825, nenhum dos 16 produtores com safra superior a 500 alqueires declarou vender ao menos parte do que foi produzido, assim como ocorreu em 1830: 12 domicílios com produção acima de 500 alqueires e nenhuma referência à comercialização de tal produção. Neste último ano, entre os chefes considerados encontramos sete senhores de engenho, com plantéis cativos que iam de 20 a 89 indivíduos. Antonio Pires Pimentel produziu 700 alqueires de milho e declarou ter sua tropa. Dez indivíduos criavam porcos, com especial atenção para o alferes Thome Joaquim de Passo, que declarou naquele ano 100 capados, que a se considerar os números apresentados por Mawe e Schewege citados por Luna $(2006,129)$, deveriam consumir cada um, em períodos de criação de oito a doze meses, entre 200 e 250 quilos de milho (aproximadamente 6,6 a 8,3 alqueires), totalizando, para a criação de tais animais, cerca de 660 a 830 alqueires, algo compatível com os 800 alqueires declarados pelo alferes, cujo fogo compunha-se ainda de sua mulher, seis filhos e 47 escravos. Decrescendo a faixa de produção para 300,1 alqueires, em 1830 encontramos 84,4\% (27 em 32) dos produtores também como criadores de porcos - percentual idêntico encontramos em 1816. 
Tabela 3 - Média e distribuição de produtores e produção de milho de acordo com faixas de alqueires; participação das faixas de alqueires no volume de milho vendido (1799 a 1830)

\begin{tabular}{|c|c|c|c|c|c|c|c|c|c|c|c|c|c|c|c|}
\hline \multirow{4}{*}{$\begin{array}{l}\text { Faixas de } \\
\text { alqueires }\end{array}$} & \multicolumn{4}{|c|}{1799} & \multicolumn{5}{|c|}{1803} & \multicolumn{6}{|c|}{1808} \\
\hline & \multicolumn{4}{|c|}{ Média = 59,3 alq. } & \multicolumn{5}{|c|}{ Média = 84,9 alq. } & \multicolumn{6}{|c|}{ Média = 86,8 alq. } \\
\hline & Produtores & Volume & \multicolumn{2}{|c|}{ Venda } & Produtores & \multicolumn{2}{|c|}{ Volume } & \multicolumn{2}{|c|}{ Venda } & \multicolumn{2}{|r|}{ Produtores } & \multicolumn{2}{|c|}{ Volume } & \multicolumn{2}{|c|}{ Venda } \\
\hline & № (\%) & Alq. (\%) & № & $\begin{array}{l}\% \\
\text { Alq. }\end{array}$ & № (\%) & \multicolumn{2}{|c|}{ Alq. (\%) } & № & $\begin{array}{l}\% \\
\text { Alq. }\end{array}$ & \multicolumn{2}{|c|}{ № (\%) } & \multicolumn{2}{|c|}{ Alq. (\%) } & \multicolumn{2}{|c|}{ № $\begin{array}{l}\% \\
\text { Alq. }\end{array}$} \\
\hline Até 10 & $40(12,7)$ & $345(1,8)$ & 8 & 13,3 & $30(6,9)$ & 265 & $5(0,7)$ & - & - & & $20(9,0)$ & 194 & $(1,0)$ & - & - \\
\hline 10,1 a 50 & $207(65,5)$ & $6374(34,0)$ & 26 & 8,3 & $241(55,7)$ & 7455 & $5(20,3)$ & 4 & 1,5 & & $23(55,7)$ & 3623 & $(18,9)$ & 5 & 1,0 \\
\hline 50,1 a 100 & $41(13,0)$ & $3425(18,3)$ & 13 & 10,9 & $91(21,0)$ & 7409 & $9(20,2)$ & 6 & 4,1 & & $45(20,4)$ & 3770 & $(19,6)$ & 10 & 10,8 \\
\hline 100,1 a 300 & $19(6,0)$ & $3615(19,3)$ & 8 & 18,3 & $55(12,7)$ & 10181 & $1(27,7)$ & 14 & 22,8 & & $23(10,4)$ & 4051 & $(21,1)$ & 7 & 14,4 \\
\hline 300,1 a 500 & $6(1,9)$ & $2600(13,9)$ & 2 & 17,3 & $7(1,6)$ & 3025 & $5(8,2)$ & 2 & 8,8 & & $4(1,8)$ & 1730 & $(9,0)$ & - & - \\
\hline 500,1 ou mais & $3(0,9)$ & $2370(12,7)$ & 1 & 8,4 & $9(2,1)$ & 8430 & $0(22,9)$ & 3 & 29,1 & & $6(2,7)$ & 5820 & $(30,3)$ & 2 & 14,2 \\
\hline Total & $316(100,0)$ & $18729(100,0)$ & 58 & 12,1 & $433(100,0)$ & 36765 & $5(100,0)$ & 29 & 11 & & $21(100,0)$ & 19188 & $(100,0)$ & 24 & 6,9 \\
\hline \multirow{4}{*}{$\begin{array}{l}\text { Faixas de } \\
\text { alqueires }\end{array}$} & & 1816 & & & & 18 & 22 & & & & & 182 & & & \\
\hline & & édia = 109,8 alq. & & & & édia $=$ & 88,2 alq. & & & & & édia = 11 & 13,3 alq. & & \\
\hline & Produtores & Volume & & nda & Produtores & & lume & & nda & & Produtores & Volu & ume & & nda \\
\hline & № (\%) & Alq. (\%) & № & $\begin{array}{l}\% \\
\text { Alq. }\end{array}$ & № (\%) & & q. (\%) & № & $\begin{array}{l}\% \\
\text { Alq. }\end{array}$ & & № (\%) & Alq. & . $\%)$ & № & $\begin{array}{l}\% \\
\text { Alq. }\end{array}$ \\
\hline Até 10 & $19(3,8)$ & $162(0,3)$ & - & - & $18(4,2)$ & & $6(0,4)$ & - & - & & $21(3,9)$ & 166 & $(0,3)$ & - & - \\
\hline 10,1 a 50 & $244(48,7)$ & $7954(14,5)$ & 3 & 1,6 & $261(60,8)$ & 8704 & $4(23,0)$ & - & - & & $70(50,4)$ & 9103 & $(15,0)$ & 2 & 0,6 \\
\hline 50,1 a 100 & $114(22,8)$ & $9634(17,5)$ & 3 & 1,6 & $75(17,5)$ & 6660 & $0(17,6)$ & - & - & & $13(21,1)$ & 9562 & $(15,7)$ & 8 & 6,0 \\
\hline 100,1 a 300 & $92(18,4)$ & $17054(31,0)$ & 7 & 16,8 & $53(12,4)$ & 10540 & $0(27,9)$ & 2 & 2,6 & & $92(17,2)$ & 18644 & $(30,7)$ & 10 & 14,1 \\
\hline 300,1 a 500 & $23(4,6)$ & $10180(18,5)$ & - & - & $14(3,3)$ & 5900 & $0(15,6)$ & 2 & 6,9 & & $24(4,5)$ & 10318 & $(17,0)$ & 2 & 5,4 \\
\hline 500,1 ou mais & $9(1,8)$ & $10025(18,2)$ & 2 & 16,9 & $8(1,9)$ & 5900 & $0(15,6)$ & 1 & 8,4 & & $16(3,0)$ & 12950 & $(21,3)$ & - & - \\
\hline Total & $501(100,0)$ & $55009(100,0)$ & 15 & 6,21 & $429(100,0)$ & 37840 & $0(100,0)$ & 5 & 2,5 & & $36(100,0)$ & 60743 & $(100,0)$ & 22 & 4,8 \\
\hline & & 1830 & & & & & & & & & & & & & \\
\hline & & édia $=144,2$ alq. & & & & & & $\%$ do & vol & ume da & las vendas & & & & \\
\hline alqueires & Produtores & Volume & & $\frac{n d a}{\%}$ & $\begin{array}{l}\text { Faixas d } \\
\text { alqueire }\end{array}$ & & 1799 & 1803 & & 1808 & 1816 & 1822 & 1825 & & 830 \\
\hline & № (\%) & Alq. (\%) & № & $\begin{array}{l}\% \\
\text { Alq. }\end{array}$ & Até 10 & & 13,8 & - & & - & - & - & - & & - \\
\hline Até 10 & $14(3,6)$ & $129(0,3)$ & - & - & 10,1 a 5 & & 44,8 & 13,8 & & 20,8 & 20,0 & - & 9,1 & & 9,1 \\
\hline 10,1 a 50 & $179(46,5)$ & $5777(11,7)$ & 1 & 0,5 & 50,1 a 10 & & 22,4 & 20,7 & & 41,7 & 20,0 & - & 36,4 & & 8,2 \\
\hline 50,1 a 100 & $\begin{array}{l}85(22,1) \\
75 \quad(19,5)\end{array}$ & $\begin{array}{c}1083(2,2) \\
14447(29,2)\end{array}$ & $\begin{array}{l}2 \\
4\end{array}$ & $\begin{array}{l}2,3 \\
89\end{array}$ & 100,1 a 3 & & 13,8 & 48,3 & & 29,2 & 46,7 & 40,0 & 45,5 & & 36,4 \\
\hline $\begin{array}{l}100,1 \text { a } 300 \\
300,1 \text { a } 500\end{array}$ & $\begin{array}{l}75(19,5) \\
20(5,2)\end{array}$ & $\begin{array}{r}14447(29,2) \\
8281(16,7)\end{array}$ & $\begin{array}{l}4 \\
4\end{array}$ & $\begin{array}{c}8,9 \\
17,3\end{array}$ & 300,1 a 5 & & 3,4 & 6,9 & & - & - & 40,0 & 9,1 & & 36,4 \\
\hline 500,1 ou mais & $12(3,1)$ & $19812(40,0)$ & - & - & 500,1 ou $n$ & mais & 1,7 & 10,3 & & 8,3 & 13,3 & 20,0 & - & & - \\
\hline Total & $385(100,0)$ & $49529(100,0)$ & 11 & 4,7 & Total & & 100,0 & 100,0 & & 100,0 & 100,0 & 100,0 & 100,0 & & 00,0 \\
\hline
\end{tabular}

As grandes colheitas do cereal estavam ligadas a fogos com grande número de indivíduos e/ou animais, que apesar do elevado montante produzido tendiam a consumi-los na própria unidade produtiva não sendo, de forma considerável, transacionados por esses produtores; especialmente ao final do período, quando se vê aumentada a população e o número de engenhos na vila de Jundiaí. Ao que parece, aqueles que produziam entre 10,1 e 300 alqueires eram os maiores responsáveis pela comercialização do milho jundiaense. 
O milho levado ao mercado apresentou preços reais bastante variáveis ao longo dos anos, como se vê no Gráfico 2. Entre os anos para os quais obtivemos a informação de preço constatamos o pico em 1808, quando o preço real médio do milho praticado na localidade superou os $\$ 400$ por alqueire, sendo esse elevado valor coincidente com a menor produção total do gênero em tela. Apenas a partir de 1814 conseguimos observar novamente o preço do milho no mercado jundiaense, ano em que o preço foi inferior aos $\$ 200$, tendo caído a pouco mais de $\$ 130$ já em 1816, não chegando ao preço médio de 1814 até 1818 . Entre 1822 e 1827 o preço do milho cresceu, tendo sua produção (disponibilidade) seguido o aumento verificado para os preços. Em 1828, a produção do milho foi a maior verificada, tendo o preço respondido negativamente, e caído em mais de $\$ 50$ por alqueire (queda de $28 \%$ ), tendo a produção caído já no ano seguinte. Vale lembrar que o período 1827-29 foi aquele em que se ampliou a participação do milho no valor das exportações da vila de Jundiaí e ainda o percentual do bem enviado para fora das fronteiras da localidade.

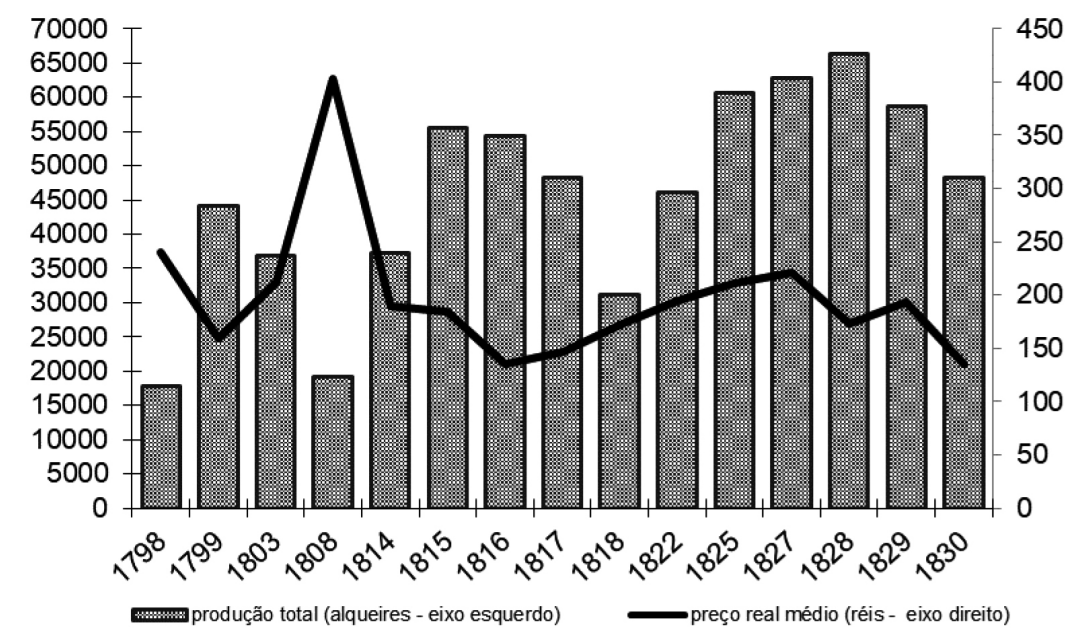

Gráfico 2 - Evolução do volume total produzido e do preço real médio do milho (1798 a 1830) 
Assim, do exposto nas últimas páginas, podemos destacar a presença de um mercado de víveres bem desenvolvido, com considerável grau de mercantilização e dinamização através do comércio local e/ou das articulações entre diferentes regiões. Tem sido destacada a importância da parcela da população envolvida em atividades de subsistência e abastecimento, em especial, o elevado contingente de pequenos e médios lavradores. Esses agricultores produziam visando ao comércio ou, mesmo na ausência desse objetivo precípuo, obtendo excedentes substanciais capazes de abastecer o mercado.

Diferente do milho, o açúcar possuía um destino bem definido: o mercado externo via porto de Santos (ou Santos - Rio de Janeiro). A cidade de São Paulo recebeu parte do açúcar jundiaense, contudo, a maior parcela da produção era enviada àquela vila portuária.

Apesar da sua importância inegável na produção local, longe de se espalhar por uma vasta gama de domicílios, o açúcar e seus montantes produzidos e/ou comercializados foram arrolados em poucos fogos (Tabela 4). Entre 1799 e 1808, o número variou entre 14 e 17, caiu para nove em 1812, subiu a 22 em 1816, chegando a 33 produtores em 1822-25. Parece clara, então, a grande ampliação do número de indivíduos envolvidos no mercado do açúcar; mercado este que viu ampliado não só o número de seus produtores/ vendedores, como também o volume devido a cada um deles e, por conseguinte, o volume total de açúcar produzido, observação que acompanha o ocorrido com a produção da capitania/província em seu conjunto:

Segundo o 'Mapa dos Engenhos de açúcar' elaborado por Melo Castro e Mendonça, pode-se calcular, para o ano de 1798 a média de 314,3 arrobas por engenho e, para 1799, 345,7 arrobas. Em 1836 usando os dados de D. P. Müller, a média por engenho seria de 977,6 arrobas. Para 1854, portanto no fim do ciclo do açúcar, a média calculada com elementos fornecidos por Machado d'Oliveira é de 1388 arrobas por engenho. Houve, portanto, aumento gradativo no rendimento médio de um engenho em São Paulo. (Petrone 1968, 106) 
Em Jundiaí, na virada do século XVIII para o XIX, foram anotados, em média, 333 arrobas por produtor, montante que ao final do período estudado (1830) já havia atingido mais de 775 arrobas de açúcar, entre fino, redondo e mascavo. O mínimo havia sido de 40 arrobas em 1799, em 1830 era três vezes maior: 120 arrobas. Da mesma maneira, o extremo superior da produção situava-se em 1200 arrobas ao final do Setecentos, tendo dobrado passados 30 anos: Escolástica Joaquina de Barros produziu 2400 arrobas. Neste ano, a moda foi 1000 arrobas com mediana 700 arrobas. Variações ocorreram nos valores apurados com destaque para 1803, quando o maior senhor de engenho açucareiro produziu tão somente 530 arrobas; e em 1812, Francisco Xavier Vaz produziu 130 arrobas, sendo o menor volume declarado naquele ano, mas $115 \%$ maior do que o correspondente poucos anos antes, $1808 .^{8}$

8 Havia importante concentração dos escravos nos fogos com presença da produção comercial do açúcar. Como temos mostrado, o açúcar esteve presente em pequeno, mas crescente número de fogos. A ampliação ocorreu não somente no número observado de unidades produtivas, mas também no montante de produto saído destes fogos. Em Jundiaí, as estatísticas observadas para os produtores de açúcar apresentam-se sempre em valor superior àquelas observadas para a totalidade dos detentores de escravos. O número de escravos em domicílios com a presença de engenhos e produção de açúcar subiu de 223 indivíduos em 16 fogos em 1799 a 1082 indivíduos em 29 fogos em 1830, um aumento nominal de $385 \%$. Essa mudança respondeu por médias flutuantes e elevadas, correspondentes, dadas as características da posse de cativos na localidade, a escravarias de tamanho grande a muito grande: em 1799 a média observada foi de 13,9 cativos por fogo, em 1812 eram 22,5 escravos em cada unidade produtiva, número próximo aos 21,9 encontrados em 1822 e inferior à maior média calculada para 1830, 37,3 escravos; ano em que a mediana esteve em 25 - igual àquela calculada para 1816 e próximas às de $1808,22,5$, e 1825, 23 escravos - ou seja, ao menos 15 entre os produtores de açúcar em 1830 possuíam 25 ou mais escravos. Assim, não estranha termos nos deparado com percentual bastante elevado dos escravos em Jundiaí na produção de açúcar. No Setecentos, 32,8\% dos cativos tinham vínculo direto com o açúcar (na medida em que eram encontrados nos mesmos fogos) e, especialmente a partir de 1816, quando se vê aumentado o número de produtores, o percentual atinge $48,3 \%$ em 1816, finalizando o período em 53,2\%, após ter sido de 57,7\% em 1822 . Ou seja, nas décadas finais observadas quase dois terços dos escravos encontrados no recenseamento jundiaense foram anotados junto a chefes produtores de açúcar. 
Tabela 4 - Média e distribuição de produtores e produção de açúcar de acordo com faixas de arrobas (1799 a 1830)

\begin{tabular}{|c|c|c|c|c|c|c|}
\hline \multirow{4}{*}{$\begin{array}{c}\text { Faixas de } \\
\text { arrobas }\end{array}$} & \multicolumn{2}{|c|}{1799} & \multicolumn{2}{|c|}{1803} & \multicolumn{2}{|c|}{1808} \\
\hline & \multicolumn{2}{|c|}{ Média $=336,6$ arrobas } & \multicolumn{2}{|c|}{ Média $=208,2$ arrobas } & \multicolumn{2}{|c|}{ Média $=384,9$ arrobas } \\
\hline & Produtores & Volume & Produtores & Volume & Produtores & Volume \\
\hline & № (\%) & Arrobas (\%) & № (\%) & Arrobas (\%) & № (\%) & Arrobas (\%) \\
\hline Até 50 & $2(12,5)$ & $90(1,7)$ & $3(21,4)$ & $135(4,6)$ & $(0,0)$ & $(0,0)$ \\
\hline 50,1 a 100 & $2(12,5)$ & $180(3,4)$ & $2(14,3)$ & $180(6,2)$ & $2(11,8)$ & $159(2,4)$ \\
\hline 100,1 a 500 & $11(68,8)$ & $3868(72,5)$ & $8(57,1)$ & $2050(70,3)$ & $8(47,1)$ & $1525(23,3)$ \\
\hline 500,1 a 1000 & $(0,0)$ & $(0,0)$ & $1(7,1)$ & $550(18,9)$ & $7(41,2)$ & $4860(74,3)$ \\
\hline 1000,1 ou mais & $1(6,3)$ & $1200(22,5)$ & $(0,0)$ & $(0,0)$ & $(0,0)$ & $(0,0)$ \\
\hline Total & $16(100,0)$ & $5338 \quad(100,0)$ & $14(100,0)$ & $2915(100,0)$ & $17(100,0)$ & $6544(100,0)$ \\
\hline \multirow{4}{*}{$\begin{array}{l}\text { Faixas de } \\
\text { alqueires }\end{array}$} & \multicolumn{2}{|c|}{1812} & \multicolumn{2}{|c|}{1816} & \multicolumn{2}{|c|}{1822} \\
\hline & \multicolumn{2}{|c|}{ Média $=510,0$ arrobas } & \multicolumn{2}{|c|}{ Média $=433,4$ arrobas } & \multicolumn{2}{|c|}{ Média $=587,0$ arrobas } \\
\hline & Produtores & Volume & Produtores & Volume & Produtores & Volume \\
\hline & № (\%) & Arrobas (\%) & № (\%) & Arrobas (\%) & № (\%) & Arrobas (\%) \\
\hline Até 50 & $(0,0)$ & $(0,0)$ & $1(4,5)$ & $40(0,4)$ & $(0,0)$ & $(0,0)$ \\
\hline 50,1 a 100 & $(0,0)$ & $(0,0)$ & $1(4,5)$ & $81(0,8)$ & $5(15,2)$ & $471(2,4)$ \\
\hline 100,1 a 500 & $5(55,6)$ & $1470(32,0)$ & $13(59,1)$ & $4014(42,1)$ & $13(39,4)$ & $4281(22,1)$ \\
\hline 500,1 a 1000 & $3(33,3)$ & $2110(46,0)$ & $6(27,3)$ & $3900(40,9)$ & $9(27,3)$ & $6950(35,9)$ \\
\hline 1000,1 ou mais & $1(11,1)$ & $1010(22,0)$ & $1(4,5)$ & $1500(15,7)$ & $6(18,2)$ & $7670(39,6)$ \\
\hline Total & $9(100,0)$ & $4590 \quad(100,0)$ & $22(100,0)$ & $9535(100,0)$ & $33(100,0)$ & $19372(100,0)$ \\
\hline \multirow{4}{*}{$\begin{array}{l}\text { Faixas de } \\
\text { alqueires }\end{array}$} & \multicolumn{2}{|c|}{1825} & \multicolumn{2}{|c|}{1830} & & \\
\hline & \multicolumn{2}{|c|}{ Média $=609,1$ arrobas } & \multicolumn{2}{|c|}{ Média $=775,8$ arrobas } & & \\
\hline & Produtores & Volume & Produtores & Volume & & \\
\hline & № (\%) & Arrobas (\%) & № (\%) & Arrobas (\%) & & \\
\hline Até 50 & $(0,0)$ & $(0,0)$ & $(0,0)$ & $(0,0)$ & & \\
\hline 50,1 a 100 & $2(6,1)$ & $190(0,9)$ & $(0,0)$ & $(0,0)$ & & \\
\hline 100,1 a 500 & $17(51,5)$ & $5570(27,7)$ & $12(41,4)$ & $3640(16,2)$ & & \\
\hline 500,1 a 1000 & $9(27,3)$ & $7850(39,1)$ & $13(44,8)$ & $11357(50,5)$ & & \\
\hline 1000,1 ou mais & $5(15,2)$ & $6490(32,3)$ & $4(13,8)$ & $7500(33,3)$ & & \\
\hline Total & $33(100,0)$ & $20100(100,0)$ & $29(100,0)$ & $22497(100,0)$ & & \\
\hline
\end{tabular}

Apesar de elevados para alguns senhores, os volumes médios da produção açucareira em Jundiaí eram inferiores aos verificados para outras regiões (especialmente o nordeste) e períodos. De acordo com Petrone (1968, 106-7): 
Com os dados que Antonil (1710) nos fornece, pode-se calcular uma média de 2450 arrobas de açúcar para os engenhos dos Brasil. A média para os engenhos da Bahia era de 2791 arrobas, para os de Pernambuco 1750 arrobas e para os do Rio de Janeiro, 2630 arrobas. Manuel Ferreira da Câmara, descrevendo a capitania de Ilhéus, em 1789, afirmava que o senhor de engenho, que em qualquer parte do Brasil fazia 1000 pães de três arrobas, podia ser considerado grande lavrador. Pizzarro e Araújo afirma que nos campos dos Goitacazes poucas fábricas faziam anualmente mais que 40 caixas de açúcar e 'de ordinário chegam a menos de 30'. Caculando 35 arrobas para uma cai$x a$, a produção de um engenho seria de 1050 a 1400 arrobas.

Parcela majoritária dos engenhos situava-se na faixa de produção de 100 a 500 arrobas faixa que, apenas em 1799 e 1803, respondeu à maior parcela da produção: $72,5 \%$ e $70,3 \%$, respectivamente. A partir daí avançou o número e o volume produzidos por aqueles declarantes de 500 a 1000 arrobas, que de um único declarante em 1803 (7\%) - Domingos Pinheiro de Oliveira, com 550 arrobas declaradas -, encontramos sete em 1808 $(41,2 \%)$ e $13(44,8 \%)$ em 1830. A partir de 1822, avançou o número e a participação daqueles de cujo engenho saiu mais de 100 arrobas de açúcar. Apenas Pedro Ferraz de Arruda (4,5\%) havia produzido 1500 arrobas em 1816; a ele somaram-se outros cinco indivíduos em 1822, fazendo com que neste ano $18,2 \%$ dos produtores houvesse refinado açúcar em grandes quantidades. Corrobora-se, portanto, por outro ângulo, a expansão da produção açucareira jundiaense.

Mesmo tendo identificado o avanço no número de produtores e na produção da localidade, sabemos que diferentemente da cultura do milho, havia maiores barreiras à entrada no tocante à produção de açúcar, em virtude, sobretudo, do maior volume de capital necessário: “[...] o açúcar foi, desde o início um produto que, mesmo em sua fase de consumo apenas local, exigiu muito mais capital para o ingresso na atividade, e sua produção atraiu uma parcela menor dos agricultores." (Luna \& Klein 2006, 82). Ainda assim, alguns indivíduos chegaram à vila e seu termo com o intuito de serem ali senhores de engenho, ou ainda constatamos a criação de engenhos novos, como bem se entende com o aumento do número de fogos produtores 
do gênero e de algumas descrições mais explícitas: em 1808 Manoel Jose Fonseca, natural de São Pedro e aos 31 anos, não apareceu como produtor pois possuía "engenho novo ainda não produziu" (Lista Nominativa de Jundiaí, 1808 - AESP, Maços de População/rolo 108).

A elevação do volume produzido, todavia, ao que parece não representou para os senhores de engenho vantagem no que tange ao preço. $\mathrm{O}$ auge da produção jundiaense dentro do período 1799-1830 correspondeu aos menores preços reais médios do produto no mercado (Gráfico 3). No final do século XVII, o preço real do açúcar chegou a superar os $3 \$ 000$; na década de 1820 , flutuava em torno de $\$ 500$, em média. Assim, fato é que os preços do açúcar "na paróquia" encontraram relação com o volume ali produzido, apontando para alguma influência local no preço de comercialização, ao menos para intermediários internos do produto.

Apenas em 1799 três indivíduos declararam haver vendido parte de sua produção em suas propriedades: eram Salvador Pedroso Alvarenga (40 arrobas), Francisco Vaz Paes (200 arrobas) e Antonio Jose da Cruz (1200 arrobas, o maior volume declarado). No ano seguinte observado, Francisco não apareceu na lista, Salvador declarou "planta para gasto" e no fogo de Antonio havia menção à produção de 330 arrobas sem qualquer menção ao destino da produção.

Ademais, a expansão da produção levou não somente à queda do preço, como também à dificuldade no escoamento do açúcar. Ao menos é o que se percebe tendo-se em conta a declaração de Escolástica Joaquina que em 1825 "o açúcar vendeu pelo que comer em Santos" (Lista Nominativa de Jundiaí, 1825 - AESP, Maços de População/rolo 110). Já Jose Gomes de Oliveira, em 1808 havia produzido 150 arrobas, mas tinha em suas observações declaração mais enfática: "não vendeu porque não achou quem compra” (Lista Nominativa de Jundiaí, 1808 - AESP, Maços de População/ rolo 108). 


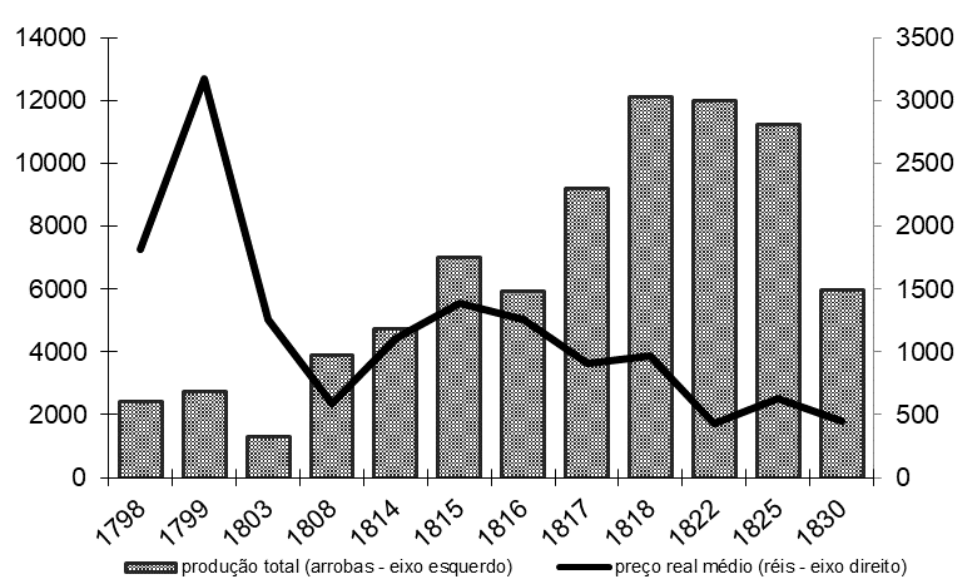

Gráfico 3 - Evolução do volume total produzido e do preço real médio do açúcar (1798 a 1830)

Se milho e açúcar fizeram parte da pauta de exportações da vila de Jundiaí, o destino de tais gêneros, assim como já havíamos verificado para as características de cada produção, foram distintos. As operações de venda do milho envolviam locais diferentes, quais sejam, a vila, a "terra" (entendida como o próprio local de produção), e a cidade de São Paulo. Sem dúvida percentual mais importante, para número de transações e volume transacionado, foi declarado na lista para vendas na terra; sendo que diretamente para São Paulo seria encaminhada pequena parcela da produção (como também um pouco de feijão, farinha, aguardente, e ainda toucinho/ capados). Decerto parte desse comércio associava-se a outros indivíduos da localidade que não agricultores, ou até mesmo agricultores que, além de produzir, necessitavam se dirigir ao mercado como consumidores, pois "o que colheu não deu para o gasto" - eis o caso de Bento Barboza Pires que em 1808 "plantou para gasto e ainda comprou mantimentos" (Lista Nominativa de Jundiaí, 1808 - AESP, Maços de População/rolo 108) Ademais, poderia haver intermediários indo até as unidades produtivas com suas tropas em busca da produção.

Ainda que grande parte dos produtores tenha declarado o comércio de açúcar, apenas pequena parcela das declarações era acompanhada do local onde foi realizada a transação. De todo modo, Santos apareceu como o principal destino da produção na maioria dos anos; deveria, decerto seguir para o porto por onde sairia do país. 
O açúcar, por representar parcela principal das exportações e por ser enviado principalmente para Santos, foi o responsável pela participação majoritária da localidade portuária na composição percentual do destino dos bens saídos de Jundiaí. Em 1799, a participação de Santos foi de 37,6\%, devido à grande participação da paróquia nas transações. Já entre 1814 e 1818 , Santos foi responsável por importar ao menos $43,4 \%$ do valor total exportado por Jundiaí, chegando a mais de $65 \%$ em 1817, enquanto verificamos a participação máxima para a cidade de São Paulo em 1815 (30,1\%), logo após a cidade apresentar percentual muito pequeno, não atingindo os $3 \%$. Parcela considerável do valor total das exportações era devido às minas de Goiás, ao menos 21\% entre 1814 e 1818, algo considerável, posto que para lá não se encaminham milho ou açúcar, mas apenas bestas e muares. Independente destas grandes variações é possível observar que entre meados e o final da década de 1810, Santos foi o principal destino dos gêneros exportados por Jundiaí, sendo seguido especialmente por Goiás e depois pela cidade de São Paulo.

Como apontado, para Goiás eram mandados exclusivamente bestas e muares, cujo comércio encontrava facilidade na localização de Jundiaí junto à rota que de São Paulo para lá seguia. Mas, de maneira diversa ao verificado para os demais produtos exportados, bestas não apareceram de maneira significativa entre as produções da localidade, sendo encontradas em apenas um ou outro fogo ao longo de todo o lapso 1799-1830. Negociados por jundiaenses, bestas e muares eram provenientes, nos primeiros anos do Oitocentos, das feiras de Curitiba e Viamão, ao Sul do Brasil.

Já nos anos dez do Oitocentos, Sorocaba era a origem dos muares reexportados de São Paulo para Goiás, de acordo com os mapas de comércio. Conhecida sua feira desde meados do século XVIII, Sorocaba transformou-se com o passar dos anos em importante centro de comercialização de tropas, reunindo vendedores e compradores que vinham ao encontro de seu mercado. A proximidade com Jundiaí possibilitou que parte desses compradores fossem habitantes da nossa vila de Jundiaí, o que possivelmente representou, com relação às feiras de Curitiba e Viamão frequentadas anteriormente, ganhos de tempo e custos de transportes para esses comerciantes de animais da vila em tela, e a consequente entrada de novos indivíduos nesse mercado. 
Esse comércio de compra e venda de muares era bastante significativo para a economia local, posto ser o segundo principal gerador de divisas externas da Vila de Jundiaí, perdendo em valor apenas para o açúcar. Os valores conjuntos para importação e exportação desses animais foram encontrados apenas para 1816,1817 e 1818. Nesses anos haviam sido importados de Sorocaba, respectivamente, 300, 325 e 630 bestas. Este número corresponde exatamente àquele exportado para Goiás nos referidos anos. Nominalmente, os preços de importação eram de $11 \$ 000$ em 1817 e $12 \$ 000$ em 1816 e 1818, enquanto os valores nominais de exportação foram de $16 \$ 000$ nos três anos. Assim, temos em 1816 importações que nominalmente foram de 3:600\$000, contra 4:800\$000 para as exportações, sendo o líquido de 1:200\$000. No ano seguinte, as exportações nominais líquidas alçaram-se a 1:625\$000, para 3:575\$000 de importações e 5:200\$000 em importações. Já em 1818 o número de muares transacionados dobrou com relação aos anos anteriores, movimentando em compras 7:560\$000 e em vendas 10:080\$000, uma diferença de 2:520\$000, ou seja, cerca de $33 \%$.

Apesar de produzir alguns gêneros de subsistência em grande monta, diferentes gêneros mais sofisticados chegavam a Jundiaí vindos de outros mercados. Ao longo do período 1799 a 1825, para os anos em que os mapas de comércio apresentavam estes dados, encontramos presença de Santos e Rio de Janeiro, portos onde desembarcavam uma série destes produtos vindos, inclusive de além mar. Em alguns momentos temos menção à cidade de São Paulo e em 1800 e 1801 gêneros haviam chegado da Bahia. ${ }^{9}$

Nos anos em que estiveram presentes na pauta de importações, responderam pelo percentual majoritário do valor das importações locais; apenas em 1809 o Rio de Janeiro apareceu como ponto de partida de mercadorias de valor superior, $41,2 \%$, enquanto os potros e bestas oriundos de Curitiba responderam por $37,9 \%$ das importações jundiaenses. Nos demais anos, apesar de majoritários os percentuais foram bastante variáveis: 60,5\% em 1800 e $82,6 \%$ já no ano seguinte, por exemplo. O mesmo ocorreu quando a origem dos animais era Sorocaba, entre 1812 e 1818: 84,2\% no primeiro ano, caindo a $57,3 \%$ no ano seguinte e subindo a $72,4 \%$ passados outros dois anos.

9 Entre os bens importados podemos encontramos sal, vinho, vinagre, aguardente de quina, panos, tecidos, meias, chapéus, pape, retrós, vinho, ferro, aço, fazendas secas. 
Este comércio com outras regiões, acreditamos, era dinamizado especialmente pela comercialização do açúcar produzido localmente e pela intermediação na venda dos muares, os dois principais componentes da pauta de exportações de Jundiaí. Decerto a importância assumida por estes gêneros e as modificações mercantis que para eles observamos, fizeram com que se mostrassem mais ou menos atrativos os distintos setores econômicos, justificando as modificações na composição das ocupações da localidade, apresentadas à frente.

\section{Atividades Produtivas}

Diretamente vinculadas ao setor comércio temos as atividades dentro do setor de transportes, em grande medida ligado ao escoamento da produção, como fica claro em algumas situações, a exemplo daquelas encontradas no arrolamento de 1799, em que Pedro Vaz de Lima, Vitorino de Godois e Joaquim dos Reis tinham anotado em suas observações: "vive de conduzir açúcar para Santos". (Lista Nominativa de Jundiaí, 1799 - AESP, Maços de População/rolo 106) Ademais, o serviço de transportes deveria abrir outras possibilidades correlatas como encontramos em 1808 o caso de Manoel de Arruda que aos 76 anos "vive de arrancar capim e vender para as tropas". (Lista Nominativa de Jundiaí, 1808 - AESP, Maços de População/rolo 108)

Deveriam sofrer mais diretamente com as flutuações do mercado também os jornaleiros, que por viverem de seu jornal, ou seja, pelo pagamento de um dia de trabalho, dependiam das condições de seus possíveis pagadores, que por sua vez dependiam da dinâmica econômica local. Em 1799, o percentual desses chefes de fogo atingiu 4,2\% em 1808 e 1816 caiu a pouco mais de $1 \%$, em 1822 foi de $5,2 \%$ e ao fim do período, 1830, chegou a 6,9\% (cf. Tabela 5). Por exemplo, Domingos da Cruz vivia de seus jornais em 1799, e foi encontrado como plantador para gasto nos anos seguintes (1803 e 1808), o mesmo acontecendo, por exemplo, com Eleutério Pires. Ou ainda podemos citar Angelo de Lima, que em 1799 vivia de seus jornais, em 1803 vivia de suas lavouras, cinco anos depois foi encontrado novamente como jornaleiro e passados mais cinco anos declarou plantar para gasto. 
Assim, acreditamos ter ocorrido em Jundiaí um efeito multiplicador, à la Keynes, nos moldes daquele identificado por Robert Slenes (1988) para a economia mineira no século XIX, a partir de seu centro dinâmico exportador. ${ }^{10}$ É dizer, Jundiaí possuía um setor exportador capaz de gerar significativas divisas e que possuía razoável importância. Em que pese a parcela devida ao setor ligado ao comércio para além das fronteiras coloniais, essas atividades exportacionistas causavam impacto sobre o já estabelecido setor agrícola de abastecimento interno, estimulando ainda mais sua veia comercial e incentivando ainda outras atividades diversas, espraiando e ampliando atividades comerciais e manufatureiras, assim como intensificando a importância dos indivíduos ligados ao transporte.

Essas modificações podem ser notadas na análise da estrutura ocupacional dos fogos da localidade. Segundo os maços de população analisados para o período 1799 a 1830, para a então vila de Jundiaí e seu termo, a sociedade jundiaense era acentuadamente rural, mas com importante participação de domicílios cujas atividades econômicas principais estavam ligadas a setores como artesanato, transporte ou comércio, serviços básicos também para quem se dedicava à agropecuária. Na Tabela 5 são mostrados os principais setores em que podemos classificar as atividades econômicas arroladas para os chefes de fogo da localidade ao longo dos anos.

10 "Este setor exportador, por sua vez, teve um impacto sobre a economia interna. As pessoas nele envolvidas precisavam comer e provavelmente compravam pelo menos uma parte de seus mantimentos. Além disso, o transporte de produtos de algodão para as regiões cafeeiras criava empregos para tropeiros, livres e escravos, que, por sua vez, estimulavam o mercado doméstico [...] E havia ainda ligações terciárias: o abastecimento dos tropeiros e dos condutores de gado bovino e suíno no setor exportador e o suprimento dos fazendeiros e sitiantes (que produziam mantimentos para estes trabalhadores e seus animais) criavam mais empregos nos transportes, o que estimulava mais uma vez a procura no mercado interno." (Slenes 1988, 460-461) 
Tabela 5 - Distribuição dos fogos por setores de atividade econômica (1799 a 1830)

\begin{tabular}{|c|c|c|c|c|c|c|c|c|}
\hline Setor & $\begin{array}{c}1799 \\
\%\left(\mathrm{~N}^{\circ}\right)\end{array}$ & $\begin{array}{r}1803 \\
\%\left(\mathrm{~N}^{\circ}\right)\end{array}$ & $\begin{array}{r}1808 \\
\%\left(\mathrm{~N}^{\circ}\right)\end{array}$ & $\begin{array}{r}1812 \\
\%\left(\mathrm{~N}^{\circ}\right)\end{array}$ & $\begin{array}{r}1816 \\
\%\left(\mathrm{~N}^{\circ}\right)\end{array}$ & $\begin{array}{r}1822 \\
\%\left(\mathrm{~N}^{\circ}\right)\end{array}$ & $\begin{array}{r}1825 \\
\%\left(\mathrm{~N}^{\circ}\right)\end{array}$ & $\begin{array}{r}1830 \\
\%\left(\mathrm{~N}^{\circ}\right)\end{array}$ \\
\hline Agricultura & $71,6(442)$ & $50,6(316)$ & $55,9(329)$ & $53,1(391)$ & $48,9(370)$ & $45,3(315)$ & $50,3(406)$ & $47,5(406)$ \\
\hline Artesanato & $6,3(39)$ & $10,9(68)$ & $12,4(73)$ & $12,2(90)$ & $14,9(113)$ & $15,2(106)$ & $16,7(135)$ & $17,2(147)$ \\
\hline Igreja & $0,5(3)$ & $0,6(4)$ & $0,7(4)$ & $0,5(4)$ & $0,4(3)$ & $0,3(2)$ & $0,2(2)$ & $0,4(3)$ \\
\hline Magistratura & $0,2(1)$ & $0,5(3)$ & $0,8(5)$ & $0,4(3)$ & $0,1(1)$ & $0,3(2)$ & $0,2(2)$ & $0,5(4)$ \\
\hline Profissões liberais & $0,2(1)$ & $0,2(1)$ & $0,3(2)$ & $0,0(0)$ & $0,0(0)$ & $0,1(1)$ & $0,1(1)$ & $0,2(2)$ \\
\hline Rentistas & $0,2(1)$ & $0,2(1)$ & $0,7(4)$ & $0,5(4)$ & $0,3(2)$ & $0,6(4)$ & $0,2(2)$ & $0,2(2)$ \\
\hline Comércio & $2,4(15)$ & $1,9(12)$ & $1,7(10)$ & $1,4(10)$ & $2,2(17)$ & $3,9(27)$ & $3,8(31)$ & $7,0(60)$ \\
\hline Transporte & $2,9(18)$ & $8,0(50)$ & $6,3(37)$ & $3,3(24)$ & $7,4(56)$ & $5,7(40)$ & $6,2(50)$ & $5,7(49)$ \\
\hline Serviços em geral & $0,2(1)$ & $0,0(0)$ & $0,0(0)$ & $0,0(0)$ & $0,0(0)$ & $0,1(1)$ & $0,1(1)$ & $0,5(4)$ \\
\hline Corpo militar & $1,9(12)$ & $0,3(2)$ & $1,4(8)$ & $0,9(7)$ & $0,7(5)$ & $0,3(2)$ & 0,1 (1) & $0,2(2)$ \\
\hline Jornaleiros & $4,2(26)$ & $3,0(19)$ & $1,2(7)$ & $3,4(25)$ & $1,3(10)$ & $5,2(36)$ & $2,7(22)$ & $6,9(59)$ \\
\hline Não classificadas & $0,5(3)$ & $3,5(22)$ & $0,0(0)$ & $1,8(13)$ & $3,7(28)$ & $0,1(1)$ & $0,1(1)$ & $0,1(1)$ \\
\hline Múltiplos setores & $8,9(55)$ & $20,3(127)$ & $18,7(110)$ & $22,5(166)$ & $20,1(152)$ & $22,8(159)$ & $19,0(153)$ & $13,6(116)$ \\
\hline Total & $100,0(617)$ & $100,0(625)$ & $100,0(589)$ & $100,0(737)$ & $100,0(757)$ & $100,0(696)$ & $100,0(807)$ & $100,0(855)$ \\
\hline
\end{tabular}

Exclusive pobres, vadios, indigentes e chefes de fogo sem ocupação declarada, que declararam "não dá nada" e ilegiveis

Fontes: AESP, Maços de População, Jundiai: anos selecionados

Encontramos o setor artesanato - em que estão arroladas, em especial, ocupações como pedreiro, louceiro, ferreiro, cangalheiro, carpinteiro/carapina, fiadeira, tecedeira, sapateiro, alfaiate, costureira, entre outras -, sempre como segundo maior empregador de chefes jundiaenses e com participação constantemente crescente ao longo do tempo. Eram 6,3\% dos fogos cuja atividade principal era o artesanato em 1799, 11\% em 1803, cerca de $12 \%$ nos anos $1808-12$, perto de $15 \%$ nos dois períodos que seguem, atingindo cerca de $17 \%$ em 1825 e 1830. Ou seja, a participação do setor foi aumentada em mais de $170 \%$ ao longo dos 30 anos observados, sendo a variação de $58 \%$ ao longo das primeiras décadas oitocentistas.

Em que pese a participação das mulheres viúvas entre os chefes de domicílio e sua ausência entre os múltiplos setores onde, como se verá, era contundente a predominância de militares, a elevação das propriedades vinculadas ao artesanato deve-se em sua maior monta à presença das atividades femininas ligadas à fiação e à tecelagem: declaradas em número de 21 em 1799 (2,1\% do total), fiadeiras, tecedeiras e costureiras alçaram-se a 97 em 1825 (12\%) e 106 no ano de 1830 , número correspondente a $12,4 \%$ das atividades encontradas para os fogos da vila. Nos últimos anos, a participação desses fogos respondia por $72 \%$ do total do setor artesanal. 
A sua vez, setor merecedor de menção é o setor relativo aos serviços de transporte. De acordo com Saint-Hilaire, em escrito da década de 1830: "Jundiaí fornece às tropas que vão a Goiás e Mato Grosso um número de camaradas ainda maior do que Moji-Mirim, e segundo me afirmaram, eles são os melhores dentre todos os distritos vizinhos. (Saint-Hilaire 1976, 114) O setor apresentou participação bastante variável ao longo do tempo, saindo de um mínimo de 2,9\% em 1799, chegou a $8 \%$ dos fogos com atividade principal declarada em 1803 e 7,4\% em 1816; percentuais que elevam-se a 3,4\%,10,1\% e 9,2\%, respectivamente, se acrescemos àqueles que também exerciam atividades militares. Esses maiores percentuais são inferiores apenas aos verificados para o setor agricultura e artesanato.

Apesar do crescente número de fogos verificados no setor transporte, ligados ao transporte, os cavalares e muares apareceram em quantidade quase nada significativa nas listas nominativas. Os cavalos deveriam estar ligados ao transporte humano, entre os bairros e localidades, por exemplo; enquanto as bestas e burros deveriam transportar carga, tendo para inúmeros indivíduos ao longo dos anos aparecido a descrição "tem sua tropa", o que implicaria possuir animais, ainda que o número deles não tenha sido explicitado, sendo o comércio desses animais bastante representativo das transações jundiaenses, como vimos.

Especialmente entre 1803 e 1825, merecem destaque entre os domicílios jundiaenses aqueles ligados a múltiplos setores, ou seja, aqueles fogos em que o chefe declarou realizar duas ou mais atividades econômicas. O percentual devido a esses fogos variou em torno dos $20 \%$ ao longo dos referidos anos, sendo a menor participação identificada em 1808 (18,7\%) e a maior em 1822 (22,8\%). Nesse sentido, a especialização não aparece de forma totalitária.

O corpo militar apresentou participação significativa na conjugação com outros setores, não menos de $79,3 \%$ das múltiplas ocupações correspondia, entre as ocupações declaradas, a militares, independente da patente considerada, sendo que não mais de 1,9\% das ocupações declaradas (correspondente a 12 indivíduos em 1799) eram exclusivamente de chefes de domicílio componentes do corpo militar. A atividade conjugada ao setor militar deveria ser a mais representativa das atividades produtivas do domicílio. 
Considerado sem distinção de patentes (de ajudante a capitão), o corpo militar esteve ligado à totalidade dos demais setores. Assim, por exemplo, encontramos em 1808 Francisco de Paula, então com 34 anos, cabo que também declarou que "vive de andar com seus animais no caminho de Santos" (Lista Nominativa de Jundiaí - AESP, Maços de População/rolo 108) ou quatro anos depois o soldado Inacio Dias "vive de ganhar jornais", assim como os soldados Manuel e Salvador de Oliveira, enquanto o soldado Joaquim Alvares era carpinteiro, o miliciano Jose dos Santos Reis era alfaiate e taberneiro, e o sargento Manoel Dias apenas colheu para gasto; entre dezenas de outras possibilidades encontradas ao longos dos anos. (cf. Lista Nominativa de Jundiaí, 1812 - AESP, Maços de População/rolo 109)

Embora tenhamos agrupado sob a rubrica "militar" indivíduos de diferentes patentes, podemos identificar algumas diferenças entre elas. As atividades ligadas ao setor artesanato aparecem, basicamente, entre os soldados, cabos ou milicianos, ou seja, o piso do serviço militar. Decerto, mesmo capazes de prover seu próprio sustento, indivíduos ligados a atividades manuais, ainda que especializadas, não apresentavam nenhum "nobreza", indispensável para ascensão aos melhores postos militares. É também entre os soldados que encontramos os militares com indicativo de produção de gêneros apenas para seu sustento e jornaleiros, certamente camadas menos abastadas da população, ainda que os primeiros tivessem alguma ligação com a terra.

Por outro lado, os postos mais altos apresentam outra especificidade: a ligação com engenhos e a produção comercial de açúcar. Os engenhos foram descritos (também ligados à "pinga") nos fogos de alguns alferes, tenentes e capitães, que deveriam controlar a produção desse bem.

Grosso modo, podemos afirmar que os fogos jundiaenses dividiam-se entre aqueles chefiados por indivíduos ligados às atividades agropastoris, e chefes ligados a outros setores de atividade, que por sua vez poderiam ser militares ou não. Em sendo militares, tenderia a acompanhar os de alta patente a agropecuária de produtos de agrícolas com vistas ao mercado, especialmente o açúcar; enquanto a baixa patente dedicar-se-ia exclusivamente à produção para o consumo próprio e eventuais negociações, e atividades manuais. 
Soldados - maior parcela dos indivíduos ligados ao corpo militar -, não estavam ligados a engenhos, havia um único cabo produzindo açúcar em 1799, era o mulato João Fernandes que produzia apenas 2,6\% do açúcar arrolado pelos oito produtores na lista nominativa daquele ano. Em 1803 e 1812, os produtores de açúcar com patente explicitamente ligadas ao corpo militar eram ao menos alferes, sendo nos demais anos os menores percentuais encontrados em 1822 (75\%), quando o soldado miliciano Ignacio Bueno declarou engenho e açúcar, e em 1825 (68,2\%), quando dois soldados milicianos, entre o total de 22 com patente, produziram o bem.

Junto aos declarados "senhor de engenho", "possui engenho", estão postos no setor agricultura aqueles indivíduos que declaram-se "agricultor", planta ou colhe "para o gasto", "vive de suas lavouras", "planta", "cria", "lavrador". As atividades mais comumente encontradas variaram de acordo com o ano da lista e, ao longo do tempo, não havia uma única descrição fixa em que os indivíduos se encontravam, ou seja, em um momento certo chefe de fogo poderia ser definido como agricultor, em outro como colheu para gasto e na próxima lista considerada ser encontrado como criador. Só para ilustrarmos com algumas poucas situações, temos Anna de Lima do Prado que em 1799 declarou plantar para gasto e viver de lavoura; já em 1803, encontramos arrolado para mesma Anna "planta e cria". Antonio Fernandes de Freitas era plantador para gasto em 1808 e agricultor em 1812; Bernardo Moraes Passos plantava para gasto e vivia de sua lavoura em 1799 e em 1803 era cabo e "não plantou". (cf. Lista Nominativa de Jundiaí,1799, 1803, 1808 e 1812 AESP, Maços de População/rolos 106 a109)

Importa notar que chefes de fogo ligados ao setor agricultura e manufatura rural representavam, como não poderia deixar de ser, parcela majoritária daqueles com ocupação declarada ao longo do período aqui observado, ainda que com uma tendência de longo prazo decrescente. Em 1830, 47,5\% de todas as ocupações listadas eram agropecuárias, percentual quase 30 pontos inferior ao observado no início do período, 1799, em que as atividades rurais responderam por $71,6 \%$ de todas aquelas anotadas. O fim do Setecentos destaca-se por apresentar participação do referido setor bastante superior àquela verificada para os demais anos, que não ultrapassou os $55,9 \%$ registrados em 1808. 
A propriedade de engenhos e a produção de açúcar estava incluída entre as ocupações do setor agricultura e manufatura rural e representava, certamente, a atividade mais representativa desse setor em termos de possibilidades mercantis da produção, sendo o açúcar produto de importante presença na pauta de exportações de Jundiaí, como se sabe.

Participação importante também era devida ao setor comércio. Vendeiros, taberneiros, negociantes que não ultrapassaram os 2,4\% dos chefes de domicílio até 1816, chegaram a 60 indivíduos em 1830, ou seja, 7\% dos domicílios do período. Entre eles destacam-se os taberneiros, que de nenhuma declaração até a primeira década do século XIX, chegava a 30 chefes de domicílio em 1830, superando os vendeiros e negociante de fazenda, mais comuns até então. Diferentemente das atividades agrícolas e artesanais que, facilmente, espraiavam-se pelas diferentes companhias que conformavam o território de Jundiaí, as casas de comércio predominavam na área mais urbana da vila, mormente na primeira companhia, em especial ao bairro da vila, ou seja, a área mais urbanizada do município. Ao menos 62,5\% (1803 e 1825) dos negócios do município ali estavam.

Em se considerando o incremento no setor comercial da localidade e observada a dinâmica populacional ocorrida em Jundiaí em semelhante período, 1799 a 1830, identificamos um crescimento bastante grande no setor comércio da ordem de $305,6 \%$, contra $47,4 \%$ da população. Observados dentro do setor apenas os negociantes e vendeiros, a variação no período seria de $114,3 \%$. Sendo uma casa comercial capaz de atender a inúmeras unidades familiares podemos aventar o incremento da circulação de bens e serviços e conseguintemente da dinâmica da economia local.

\section{População, Terra e Trabalho Escravo}

Para melhor situarmos o crescimento do comércio, assim como o incremento dos demais setores de atividade econômica apresentados, detenhamo-nos um pouco mais nas modificações ocorridas na população jundiaense nas primeiras décadas do Oitocentos. (Tabelas 6 e 7).

Em 1799 existiam ali 3876 habitantes, entre livres e escravos, espraiados por 735 fogos. Já em 1830 eram 5713 habitantes, resultantes do crescimento 
populacional ocorrido a uma taxa anual de $1,3 \%$ no decorrer do período. Os pouco mais de 30 anos observados responderam por uma variação positiva da população jundiaense de $47,4 \%$, apontados no parágrafo anterior.

Apesar da média positiva, ao longo dos anos considerados houve variação nas mudanças do número total de habitantes. O maior boom populacional ocorreu entre 1822 e 1826, quando o número de indivíduos descritos viu-se aumentado em $23,8 \%$, sendo que no período imediatamente anterior, entre 1816 e 1822, houve decréscimo na população total (-10,9\%), que passou de 4979 a 4438 pessoas. Redução no número total de habitantes ocorreu também entre 1803 e 1808, -7,4\%, logo após um crescimento de $18,3 \%$ entre 1799 e 1803.

Tabela 6 - Número de fogos e composição da população entre livres e escravos (1799 a 1830)

\begin{tabular}{l|c|cc|cc|c|c}
\hline \multirow{2}{*}{ Anos } & Fogos & \multicolumn{2}{|c|}{ Livres } & \multicolumn{2}{|c|}{ Escravos } & $\begin{array}{c}\text { População } \\
\text { total }\end{array}$ & $\begin{array}{c}\text { Relação } \\
\text { escravos/livres }\end{array}$ \\
\cline { 2 - 6 } & $\mathbf{N}^{\circ}$ & $\mathbf{N}^{\circ}$ & $\mathbf{( \% )}$ & $\mathbf{N}^{\circ}$ & $\mathbf{( \% )}$ & $\mathbf{N}^{\circ}$ & \\
\hline $\mathbf{1 7 9 9}$ & 735 & 3197 & $(82,5)$ & 679 & $(17,5)$ & 3876 & 0,21 \\
$\mathbf{1 8 0 3}$ & 743 & 3739 & $(81,5)$ & 846 & $(18,5)$ & 4585 & 0,23 \\
$\mathbf{1 8 0 8}$ & 731 & 3349 & $(78,9)$ & 897 & $(21,1)$ & 4246 & 0,27 \\
$\mathbf{1 8 1 2}$ & 838 & 3808 & $(79,0)$ & 1011 & $(21,0)$ & 4819 & 0,27 \\
$\mathbf{1 8 1 6}$ & 863 & 3774 & $(75,8)$ & 1205 & $(24,2)$ & 4979 & 0,32 \\
$\mathbf{1 8 2 2}$ & 765 & 3186 & $(71,8)$ & 1252 & $(28,2)$ & 4438 & 0,39 \\
$\mathbf{1 8 2 5}$ & 875 & 3789 & $(69,0)$ & 1704 & $(31,0)$ & 5493 & 0,45 \\
$\mathbf{1 8 3 0}$ & 910 & 3679 & $(64,4)$ & 2034 & $(35,6)$ & 5713 & 0,55 \\
\hline
\end{tabular}

Fonte: AESP, Maços de População, Jundiaí: anos selecionados 
Tabela 7 - Variação do número de fogos e da população (1799-1830)

\begin{tabular}{ccccc}
\hline Anos & $\begin{array}{c}\text { Variação \% do } \\
\text { número de } \\
\text { fogos }\end{array}$ & $\begin{array}{c}\text { Variação \% da } \\
\text { população } \\
\text { total }\end{array}$ & $\begin{array}{c}\text { Variação \% da } \\
\text { população } \\
\text { livre }\end{array}$ & $\begin{array}{c}\text { Variação \% da } \\
\text { população } \\
\text { cativa }\end{array}$ \\
\hline $\mathbf{1 7 9 9 - 1 8 0 3}$ & 1,1 & 18,3 & 17,0 & 24,6 \\
$\mathbf{1 8 0 3 - 1 8 0 8}$ & $-1,6$ & $-7,4$ & $-10,4$ & 6,0 \\
$\mathbf{1 8 0 8 - 1 8 1 2}$ & 14,6 & 13,5 & 13,7 & 12,7 \\
$\mathbf{1 8 1 2 - 1 8 1 6}$ & 3,0 & 3,3 & $-0,9$ & 19,2 \\
$\mathbf{1 8 1 6 - 1 8 2 2}$ & $-11,4$ & $-10,9$ & $-15,6$ & 3,9 \\
$\mathbf{1 8 2 2 - 1 8 2 5}$ & 14,4 & 23,8 & 18,9 & 36,1 \\
$\mathbf{1 8 2 5 - 1 8 3 0}$ & 4,0 & 4,0 & $-2,9$ & 19,4 \\
\hline
\end{tabular}

Fonte: AESP, Maços de População, Jundiai: anos selecionados

Essa variação na população total reflete em boa medida o ocorrido com a população livre, sendo esses indivíduos maioria da população - mínimo de $64,4 \%$ em 1830. Os livres tiveram seu maior crescimento também entre 1822 e 1825 (18,9\%), assim como crescimentos consideráveis entre 1808 e $1812(13,7 \%)$ e entre 1799 e 1803, quando se ampliou o número desses indivíduos de 3197 pessoas para 3739, 17\%; para também passar por um decréscimo no período seguinte, 1803-1808, desta feita de 10,4\%

Notamos que a população livre teve crescimento numérico relativamente pouco significativo entre 1799 e 1830, 15,1\% - a população total, como adiantado, cresceu acima de $47 \%$ e os escravos tiveram seu número triplicado entre 1799 e 1830 - proporcionalmente em constante declínio em relação à população cativa, que respondia por $17,5 \%$ do total de habitantes arrolados na lista nominativa jundiaense no final do Setecentos, chegando a 35,6\% da população da vila após três décadas.

Eram 679 escravos no nosso ano inicial, ultrapassando os mil indivíduos em 1812 e chegando a 1704 (31\%) em 1825; ao final do período, 1830, estavam registrados no censo 2034 cativos, que correspondiam a 35,6\% de todos os jundiaenses arrolados na lista nominativa daquele ano.

Os períodos de maior crescimento da população livre correspondem também à maior variação percentual no número de cativos na localidade que entre 1799 e 1803 tiveram seu número elevado em 24,6\%, e entre 1822 e 1825 se viram aumentados em 36,1\%. Apesar de momentos de redução da população livre, os mancípios mantiveram sempre variação positiva ainda 
que, comparativamente aos demais períodos, o crescimento de $6 \%$ ocorrido entre 1803 e 1808 e os 3,9\% de variação entre 1816 e 1822 possam ser considerados pequenos. Entre 1812 e 1816, enquanto a população livre decresceu cerca de $1 \%$, a população escrava cresceu 19,2\%.

Apenas entre 1808 e 1812 o aumento da população cativa foi inferior àquele calculado para a população livre. Todavia, esse período correspondeu àquele com maior elevação no número de fogos, que de $731 \mathrm{em} 1808$ foram encontrados em número de 838 no ano de 1812, um aumento de 14,6\% nos domicílios jundiaenses.

Ao longo das três décadas que separam 1799 de 1830, o número de cativos em Jundiaí aumentou praticamente 200\%; decerto tal incremento é efeito da expansão do setor agroaçucareiro ligado à exportação, que viu aumentado o número de cativos em seus engenhos. Processo coincidente ao verificado no Oeste paulista, região com a qual Jundiaí mantinha estreitos vínculos, senão pertencente a ela. Em nota, Bacellar (2001, 38-39) informa que

A introdução maciça de escravos nas áreas de grande lavoura sempre resultou na elevação de seu contingente. Deste modo, as vilas do Oeste paulista contavam, em 1836, escravos em proporções bastante contrastantes frente a Sorocaba: 35,4\% em Piracicaba, 42,2\% em Itu, 58,6\% em Campinas, contra 23,3\% de Sorocaba e 23,5\% em Itapetininga, também afastada do grande circuito exportador.

Para o ano de 1836 temos o Ensaio d'um quadro estatístico da província de São Paulo, de Daniel Pedro Müller, que aponta que 34,9\% da população jundiaense naquele momento era composta por cativos. E segundo Luna (2009, 339), entre 1804 e 1809, a população do Oeste Paulista cresceu a taxas de 2,07\% entre 1804 e 1829, sendo de 3,31\% a taxa anual de crescimento para o número de escravos no período.

Esses escravos se dirigiram, em especial, para plantéis de maior vulto, característicos de atividades mais mercantis. Se tomamos apenas os senhores com os maiores plantéis, considerados aqueles com mais de 20 escravos, observamos ao longo do tempo o aumento do número desses plantéis e, para além desse aumento, o número mais elevado de escravos em cada 
um deles, que de um máximo de 29 pessoas em 1799, chegou 88 escravos em 1825, pertencentes a José Castanho de Morais, o maior conjunto de escravos verificado em Jundiaí até então. No ano seguinte observado encontramos plantel semelhante: 89 pessoas.

Os referidos 89 cativos foram descritos no fogo do alferes reformado Clemente da Costa Alves, natural do Porto e que, em 1830, aos 54 anos e solteiro, encontrava-se vivendo em Jundiaí com a irmã Joaquina Maria de Jesus, quatro sobrinhos e ainda a agregada Anna Gertrudes, viúva e natural de Sorocaba, que possuía seis entre os 89 escravos arrolados no fogo. Restavam, portanto, 83 escravos a Clemente, que ainda era detentor de um dos cinco maiores grupos de cativos da Jundiaí de 1830. Manuel Soares Ferraz, assim como Roza Delfina de Camargo, também era senhor de 83 escravos e Antonio de Queiroz Telles e Jose Pereira de Queirós arrolaram 87 mancípios cada. Em comum todos declararam ser senhores de engenho e agricultores, produzindo não menos de 990 arrobas de açúcar cada um, destinado ao mercado de Santos.

De cinco indivíduos em 1799, essa faixa de tamanho de plantel passou a 23 pessoas após três décadas, um aumento de 360\% - o aumento dos domicílios no período foi de $23,7 \%$ e o de fogos com escravos de $71 \%$. Assim, houve significativa variação no percentual por eles representado: eram apenas 3,5\% dos fogos escravistas em $1799,4,2 \%$ no ano de 1803 , percentual alçado a cerca de $6,5 \%-7 \%$ em 1808 e 1812, e que esteve ao redor de $9 \%$ nos momentos observados a partir de 1816 .

A estes grandes escravistas cabia $18,4 \%$ dos mancípios arrolados para a vila e seu termo em 1799 e 54\% em 1830, ou seja,1100 indivíduos, uma média de 47,8 cativos por fogo. Em 1799 eram apenas 125 escravos anotados nos cinco plantéis muito grandes (25 por fogo) e em 1816 chegavam a 33,6 em média por domicílio.

Se paralelamente à ideia de fogo (tratado até aqui como domicílio) ${ }^{11}$ observamos a posse de terras, verificamos que $28,5 \%$ dos terrenos de Jundiaí

${ }^{11}$ Ao longo do trabalho utilizamos fogo como sinônimo de domicílio. Se para os padrões atuais a tendência é entendermos domicílio como lugar em que mora uma unidade familiar temos considerado em nosso texto, quando nos referimos a fogos ou domicílios, uma unidade econômico-familiar onde os residentes trabalhavam lado a lado, em torno de atividades específicas e organizadas, para manutenção do grupo doméstico em questão. Grupo doméstico este que, muitas vezes, era composto não somente por familiares próximos, mas também por escravos e agregados (indivíduos que não apresentavam nenhuma relação de parentesco com o núcleo familiar principal), e suas eventuais famílias, todos contabilizados como pertencentes ao fogo. 
contavam com o trabalho compulsório que estava ligado a 49,2\% da extensão rural da vila. ${ }^{12}$

Uma vez comparados ao total de domicílios - dados esses considerados para 1816, ano mais próximo ao tombamento para o qual possuímos informações censitárias - essas glebas que contavam com trabalho escravo respondiam por $10,3 \%$ deles, sendo esse praticamente o mesmo percentual daquele considerado para chefes de fogo senhores exclusivamente de escravos $(10,8 \%)$.

As propriedades arroladas no tombamento representam tão somente 36,2\% do total de fogos listados na lista nominativa de 1816 , sendo de $25,8 \%$ o percentual dos cabeças de domicílio que não contavam com trabalho cativo. Contudo, grande parte dos fogos, $53,1 \%$, não possuía nenhum dos dois principais fatores produtivos do Oitocentos: terra e trabalho escravo. A situação dessas pessoas, em especial daqueles que tinham possibilidades de manter suas atividades produtivas principais ligadas à agropecuária, ainda que em terras de outrem, não deveria ser muito diferente daquela enfrentada pelos proprietários de pequenas extensões, em sua maioria não proprietários de cativos ou, se proprietários, apenas de poucos indivíduos. Esses dados são apresentados na Tabela 8.

Entre as pequenas glebas, de até 50 alqueires paulistas, 15,1\% contava com o trabalho de escravos encontrados nessas propriedades em número de 170 (19,5\% da escravaria arrolada), em que chegaram a atingir o máximo de 26 indivíduos $(15,3 \%)$ em um único plantel, sendo a moda igual a 1 , encontrada em 8 propriedades $(28,6 \%)$.

"O capitão Joaquim José de Morais declarou possuir um terreno denominado o Rosario em que compreende 200 braças de testada e 400 de fundo [16 alqueires - DOMR] em cujo está cultivando com fábrica de açúcar e ocupa 26 escravos, e possui por compra, e nele reside". (Relação dos proprietários que possuem terrenos no distrito, e freguesia da vila de Jundiaí. 1818 - AESP, Tombamento/C09868) Além deste terreno, o capitão Joaquim possuía outra propriedade, ainda maior, 60 alqueires, em que criava animais e a qual não foi relacionado nenhum escravo.

12 Ao todo temos registradas 312 propriedades, sendo 311 com áreas identificadas no Cadastramento de terras de Jundiaí que, em conjunto, conformam uma área total de 28514,810 alqueires paulistas. Estas terras estavam nas mãos de 275 proprietários. Nenhuma propriedade era possuída por entidades. 
Tabela 8 - Fogos de acordo com a posse de terras e escravos $(1816,1818,1822)$

\begin{tabular}{|c|c|c|c|}
\hline & 1816 & 1818 & 1822 \\
\hline Número total de propriedades rurais* & & 312 & \\
\hline Número $(\%)$ de propriedades rurais com escravos & & $89(28,5 \%)$ & \\
\hline Número total de escravos no tombamento de terras* & & 904 & \\
\hline Número total de fogos & 863 & & 765 \\
\hline Número (\%) de fogos com escravos & $182(21,1 \%)$ & & $183(23,9 \%)$ \\
\hline Número total de escravos na lista nominativa & 1205 & & 1252 \\
\hline$\%$ de fogos com terras & $36,2 \%$ & & $40,8 \%$ \\
\hline$\%$ de chefes de fogo com terras e escravos & $10,3 \%$ & & $11,6 \%$ \\
\hline$\%$ de chefes de fogo sem terras e com escravos & $10,8 \%$ & & $12,8 \%$ \\
\hline$\%$ de chefes de fogo com terra e sem escravos & $25,8 \%$ & & $29,2 \%$ \\
\hline$\%$ de chefes de fogo sem terras e sem escravos & $53,1 \%$ & & $46,4 \%$ \\
\hline
\end{tabular}

*Inclusive propriedade com 34 escravos, sem área explicitada

Fontes: AESP, Inventário de Bens Rústicos, Jundiaí:1818 e AESP, Maços de População, Jundiaí: 1816,1822

Consideradas isoladamente as propriedades sem engenho de açúcar, 23\% delas tinham até 8 alqueires (tamanho da menor gleba açucareira), percentual alçado a $63,5 \%$ consideradas aqueles terrenos de até 50 alqueires. A média encontrada foi de 74,52 alqueires paulistas, consideravelmente menor que aquela verificada para os terrenos onde a produção do açúcar era levada a cabo: 258,73 alqueires.

Vinte e nove declarações mencionaram o fabrico do açúcar - número superior ao verificado nos arrolamentos populacionais de 1816 (22) e inferior aos 33 engenhos com produção registrada no recenseamento de 1822, como adiantado -, o que, dadas as já conhecidas observações sobre o açúcar, demonstra ser esta cultura praticada, de maneira típica em terras próprias. As propriedades açucareiras respondem por 9,3\% do total e $10,7 \%$ daquelas declaradas em cultura, sendo $26,3 \%$ da área declarada no inventário de bens rústicos da localidade em tela. 
De fato, ainda que não saibamos os preços de comercialização das terras locais, as características da exportação açucareira apontam significativamente para o autofinaciamento do seu desenvolvimento. E como bem apresentou Petrone (1968), em 1818, além de próprias essas propriedades haviam sido adquiridas, majoritariamente, por compra, sendo de $68 \%$ o percentual devido a essas transações, de acordo com nossos levantamentos. ${ }^{13}$

\section{Considerações Finais}

Jundiaí era ao final do século XVIII e nas primeiras décadas do Oitocentos uma economia agrária em transformação. A composição por atividades econômicas aponta para uma sociedade acentuadamente rural, com importância devida aos domicílios com atividades principais ligadas não só à produção agropecuária, mas também ao artesanato, transporte ou comércio, ou seja, serviços básicos necessários também àqueles mais fortemente vinculados à lide agrária. Assim, os fogos jundiaenses dividiam-se entre os chefiados por indivíduos ligados às atividades agropastoris, e chefes ligados a outros setores de atividade, que por sua vez poderiam ser militares ou não. Em sendo militares, tenderia a acompanhar os de alta patente a agropecuária de produtos de agrícolas com vistas ao mercado, especialmente o açúcar; enquanto a baixa patente dedicar-se-ia exclusivamente à produção para o consumo próprio e eventuais negociações, e atividades manuais.

Esses agroprodutores locais declararam a produção de diferentes tipos de gêneros agrícolas. Regra geral era a não especialização, com diferentes bens sendo encontrados na mesma unidade produtiva. Um maior número de tipos de plantações torna, para aqueles que as praticam, a especialização mais difícil indicando maior autoconsumo, ou seja, produção em quantidades limitadas que atendessem às necessidades das próprias unidades produtivas. Entre as diferentes produções destacamos e analisamos o milho e o açúcar, principais em volume e valor (excluindo-se outros tipos de ati-

${ }^{13} \mathrm{O}$ fato de se verificar no começo da cultura de cana maior número de fazendas obtidas por posse e sesmaria, para depois serem mais frequentes as obtidas por compra, permite tirar algumas conclusões quanto à origem dos capitais do ciclo do açúcar paulista. Parece que a maioria dos capitais necessários para o desenvolvimento da lavoura canavieira teria tido origem nessa mesma atividade. Tudo parece indicar que a lavoura canavieira teria autofinanciado seu desenvolvimento."(Petrone 1968, 56-58). 
vidades econômicas), e presença constante, ainda que proporcionalmente variável com o tempo, na pauta de comércio da vila; que compunham em diferentes proporções e com vistas a diferentes destinos - milho era vendido na vila, na "terra" e em São Paulo, enquanto o açúcar seguia para o porto de Santos (o açúcar, por representar parcela principal das exportações e por ser enviado principalmente para Santos, foi o responsável pela participação majoritária da localidade na composição percentual do destino dos bens saídos de Jundiaí)

O grupo de produtores de milho teve sua colheita média aumentada com o passar dos anos, e ainda que presentes na localidade produtores responsáveis pela colheita de consideráveis volumes de milho, estes não eram necessariamente aqueles responsáveis pela comercialização do cereal. Entre os poucos fogos explicitamente vendedores de milho encontramos, ao longo do tempo, aqueles enquadrados em diferentes faixas de volume de produção, contudo aqueles que mais levavam o milho ao mercado possuíam produções medianas. As grandes colheitas do cereal estavam ligadas a fogos com grande número de indivíduos (em geral cativos) e/ou animais como capados, que apesar do elevado montante produzido tendiam a consumi-los na própria unidade produtiva não sendo, de forma considerável, transacionados por esses produtores. Tal tendência acentua-se na medida em que se vê aumentada a participação da população cativa na população ao longo das décadas, em decorrência do aumento do número de engenhos. Havia importante concentração dos escravos nos fogos com presença da produção comercial do açúcar.

O incremento na produção de açúcar foi a principal transformação por que passou a economia jundiaense entre 1799 e 1830, não só pela produção em si, mas pelos reflexos dessa produção. Mesmo tendo identificado o avanço no número de produtores e na produção da localidade, sabemos que diferentemente da cultura do milho em que era fácil a mobilidade no mercado, o mercado açucareiro apresentava barreiras, por exigir muito mais investimento (leia-se, em especial, capital fixo, terra e trabalho). O açúcar modificou o panorama local, desenvolvendo o comércio e criando uma elite agrária mais pronunciada e decerto justificando formarem os donos de engenho a principal classe da terra, ainda que a produção de açúcar jundiaense não fosse comparável às das principais localidades produtoras da região oeste paulista (Itu, Porto Feliz, Campinas). 
A elevação do volume produzido, todavia, ao que parece não representou para os senhores de engenho vantagem no que tange ao preço, pois acabaram por afetá-lo: a expansão da produção levou à queda do preço do açúcar na localidade, assim como também à dificuldade no escoamento do açúcar jundiaense em momentos em que essa produção foi maior.

Levando o olhar para além de gêneros agrícolas e observando o setor comércio de forma mais específica, vemos negociados por jundiaenses bestas e muares provenientes a princípio das feiras de Curitiba e Viamão e posteriormente de Sorocaba e revendidos para a cidade de São Paulo e Goiás; seu comércio foi o segundo principal gerador de receitas externas da Vila de Jundiaí, perdendo em valor apenas para o açúcar. Juntas, as divisas geradas pela revenda de muares e a negociação de açúcar foram as principais responsáveis por manter a balança comercial da localidade positiva, o que possibilitou a aquisição de diferentes gêneros, mais ou menos sofisticados, mas não produzidos internamente à vila.

Decerto a importância assumida por estes gêneros (muares e açúcar) e as modificações mercantis que para eles observamos, fizeram com que se mostrassem mais ou menos atrativos os distintos setores econômicos, justificando as modificações na composição das ocupações/atividades econômicas da localidade: a queda da participação do setor agropecuário e um incremento das atividades de transporte, manufatureiras e principalmente de comércio.

Jundiaí possuía um setor exportador capaz de gerar significativas divisas e que possuía razoável importância. Em que pese a parcela principal devida ao setor ligado ao comércio para além das fronteiras coloniais, como açúcar, essas atividades exportacionistas causavam impacto sobre o já estabelecido setor agrícola de abastecimento interno, estimulando ainda mais sua veia comercial e incentivando ainda outras atividades diversas.

Ao longo das três décadas que separam 1799 de 1830, o número de livres aumentou cerca de $47 \%$, enquanto o número de cativos em Jundiaí aumentou praticamente 200\%; efeito da expansão do setor agro-açucareiro ligado à exportação, que viu aumentado o número de cativos em seus engenhos. Se tomamos apenas os senhores com os maiores plantéis, considerados aqueles com mais de 20 escravos, observamos ao longo do tempo o aumento do número desses plantéis e, para além desse aumento, o número mais elevado de escravos em cada um deles. 
Escravos e produção açucareira estavam ligados também à posse de terras: $68 \%$ das terras em que se produzia açúcar foram adquiridas por compra. Ainda que não saibamos os preços de comercialização das terras locais, as características da exportação açucareira apontam significativamente para o autofinaciamento do seu desenvolvimento.

\section{Referências}

\section{Fontes Manuscritas}

AESP - Arquivo do Estado de São Paulo

- Maços de população - completos: Jundiaí, 1799 (rolo 106); 1803 (rolo 107); 1808 (rolo 108); 1812 (rolo 109); 1816 (rolo 109); 1822 (rolo 110); 1825 (rolo 110); 1830 (rolo 111).

- Maços de população - resumos e mapas de produção e comércio: Jundiaí, anos diversos (rolos 105 a 111)

- Tombamento de bens rústicos: Jundiaí, 1818 (C09869 - Relação dos proprietários que possuem terrenos no distrito, e freguesia da vila de Jundiaí)

\section{Fontes Impressas}

Bacellar, C. de A. P. 1997. “Os senhores da terra - família e sistema sucessório entre os senhores de engenho do oeste paulista”, 1765-1855. Campinas: CMU/Unicamp.

Bacellar, Carlos de A. P. 2008. "Arrolando os habitantes no passado: as listas nominativas sob um olhar crítico". Locus 14: 107-124.

Canabrava, Alice Piffer. 1972. "Uma Economia de decadência: os níveis de riqueza na capitania de São Paulo, 1765/67”. In: Revista Brasileira de Economia 26 (4): 95-123.

Fernandez, Ramon V. Garcia. 1989. “A consistência das listas nominativas de habitantes da capitania de São Paulo: um estudo de caso”. Estudos Econômicos 19 (3): 477-496.

Luna, Francisco V. 2009a. "População e atividade econômicas em Areias (1817-1836).” In Luna, F. V.; Costa, Iraci del N. da \& Klein, Herbert. Escravismo em São Paulo e Minas Gerais. São Paulo: Edusp/imprensa oficial do Estado de São Paulo.

Luna, Francisco V. 2009b. "São Paulo: população, atividades e posse de escravos em vinte e cinco localidades (1777-1829).” In: Luna, F. V.; Costa, Iraci del N. da \& Klein, Herbert. Escravismo em São Paulo e Minas Gerais. São Paulo: Edusp/imprensa oficial do Estado de São Paulo. 
Luna, Francisco V. \& Klein, Herbert. 2006. "Evolução da Sociedade e Economia Escravista de São Paulo, de 1750 a 1850". São Paulo: Edusp.

Marcílio, Maria Luiza. 2000. "Crescimento Demográfico e evolução agrária paulista: 1700-1836”. São Paulo: Hucitec/Edusp.

Nozoe, N. 2008. "A apropriação de terras rurais na Capitania de São Paulo”. Livre docência. São Paulo: FEA/USP.

Nozoe, N. \& Costa, Iraci del Nero da. 1991. "Achegas para a qualificação das listas nominativas". Estudos Econômicos 21 (2):271-284, maio/ago.

Saint-Hilaire, Auguste de. 1976. "Viagem à província de São Paulo". Belo Horizonte: Itatiaia/ São Paulo: Edusp. Petrone, Maria Thereza Schorer. 1968. "A lavoura canavieira em São Paulo: expansão e declínio (1765-1851)”. São Paulo: Difusão Europeia do Livro.

Slenes, Robert W. 1988. "Os múltiplos de porcos e diamantes: a economia escrava de Minas Gerais no século XIX.” In Estudos Econômicos 18 (3): 449-495. 